This item was submitted to Loughborough's Research Repository by the author.

Items in Figshare are protected by copyright, with all rights reserved, unless otherwise indicated.

\title{
Life after the squares: reflections on the consequences of the Occupy movements
}

\section{PLEASE CITE THE PUBLISHED VERSION}

https://doi.org/10.1080/14742837.2016.1244478

\section{PUBLISHER}

(c) Taylor \& Francis

\section{VERSION}

AM (Accepted Manuscript)

\section{PUBLISHER STATEMENT}

This work is made available according to the conditions of the Creative Commons Attribution-NonCommercialNoDerivatives 4.0 International (CC BY-NC-ND 4.0) licence. Full details of this licence are available at: https://creativecommons.org/licenses/by-nc-nd/4.0/

\section{LICENCE}

CC BY-NC-ND 4.0

\section{REPOSITORY RECORD}

Fernandez-Savater, Amador, Cristina Flesher Fominaya, Luhuna Carvalho, Cigdem, Hoda Elsadda, Wiam ElTamami, Patricia Horrillo, Silvia Nanclares, and Stavros Stavrides. 2019. "Life After the Squares: Reflections on the Consequences of the Occupy Movements". figshare. https://hdl.handle.net/2134/33709. 


\title{
Life after the squares: Reflections on the consequences of the Occupy movements
}

Edited and curated by Amador Fernández-Savater and Cristina Flesher Fominaya

Contributions by Anonymous, Luhuna Carvalho, Çiğdem, Hoda Elsadda, Wiam El-Tamami, Patricia Horrillo, Silvia Nanclares, and Stavros Stavrides.

\begin{abstract}
This is a roundtable with reflections on Tahrir Square, Egypt; Syntagma Square, Greece; Rossio Square, Portugal; 15-M Puerta del Sol, Spain; Gezi Park, Turkey; and Occupy Wall Street, USA. Five years on from the birth of the movements of the streets and the squares in Tahrir Square, what has changed? This roundtable brings movement participants together in reflection on themes such as legacies, key practices and knowledge, cultural creation, and links to institutional politics. Contributors share their understanding of the situations in Egypt, Portugal, Spain, Turkey and the USA and we present their reflections in full and virtually unedited.

A full version of this special section on with additional content is also available in Spanish at the online open access journal Alexia (http://revistaalexia.es).
\end{abstract}

\section{Introduction}

The movements that swept the globe between 2011 and 2013 (known as the "movements of the squares") have undoubtedly been one of the most unique, heterogeneous events in recent times. They combine characteristics that owe much to the particularities of specific national contexts, but which at the same time resonate with each other and can be understood as part of a historical cycle; a series of struggles with shared characteristics, located within a particular period of time (Flesher Fominaya 2014). Key shared characteristics include, inter alia: the occupation of public squares (the camps), cross-

CITE Fernández-Savater, Amador and Cristina Flesher Fominaya (2016) 'Life after the squares: Reflections on the consequences of the Occupy movements' in Social Movement Studies 16(1), Online Supplement available at: www.tandfonline.com/toc/csms20/16/1 
cutting inclusivity as a key principle, the absence of leaders or clear programs, the refusal to be subordinated to particular ideological references or previously configured organizations, the rejection of representation, the practical rejection of a neoliberalism that has expanded to affect every aspect of our lives, the importance of the role of emotions and affect, and the politicization of "everyday people" and not just of activists (Flesher Fominaya 2014). ${ }^{1}$

The eruption of these movements profoundly alters the contexts in which they develop, tearing down legitimacies that seemed to be rock-solid and redefining political social and cultural reality, although in the end they seem to hit a wall (the impassivity of macropolitics) and enter into decline or give way to electoral options (old or new). But it seems to us that despite their short duration and their many problems, their potential to prefigure the future is no small thing. We believe that these movements are pregnant with key ideas that are capable of helping us to create a form of political action that can help us face the challenges of the 21 st century. They have left behind seeds that need time to grow and bear fruit. This special section seeks to interrogate the long-term impact of the movement of the squares.

At the time we began to write and prepare this special contribution to the issue on European anti-austerity protest, we were approaching the fifth anniversary of the Spanish 15-M movement, a movement we both have been closely connected to, and were feeling deeply reflexive about its consequences and possible legacies. Our mood was introspective and definitely retrospective. In the midst of our discussions Nuit Debout - the series of nightly mass protests that began in March 2016 in opposition to proposed changes in French labour laws - erupted, and Amador went off to Paris. Everywhere the participants made reference to 15-M, they sang happy birthday to the movement on May 15, and called for a Global Day of Nuit Debout on the same date. Later, the movement re-visited Spain in the Basque country, an area that had not seen strong mobilizations in 2011, but where in 2016, inspired 
by Nuit Debout (and even taking the name in Basque) activists camped out in Donosti/San Sebastian to protest an incinerator and link it to wider claims for democracy and representation. We realized, not for the first time, that what seemed to be dwindling or metamorphosing in one place was just beginning elsewhere, and that the legacies and impacts of these occupations can be felt years afterwards and in turn renew enthusiasm in the original context in a transnational feedback loop. It seemed that our reflections on the consequences of life after the squares took on a new relevance.

With this in mind, we began to wonder how others who had lived through the experience of their own squares were making sense of that experience roughly five years later. We therefore designed an open questionnaire on "Life after the squares" organized around central themes that we felt would capture some of the most profound changes and impacts of the movements, and also help organize the discussion and enable readers to draw their own conclusions and comparisons across different cases. Each theme is first presented as a set of questions that Amador and Cristina prepared to prompt reflection. Each set of answers, then, reflects different participants' reflections on the themes. The themes are: legacies; achievements, effects, and victories; cultural creation (impact in the cultural sphere); forms of life (a reflection on the transformation of social relations); normalization (attempts to deactivate or depoliticize); problems (what could have been done better); representation (links between movements and electoral options aspiring to represent them); how to carry on after the squares (the emotional and personal impact of the occupations); and between squares (cross-square inspirations and lessons).

The cases we present here have all had roughly the same period within which to reflect on the afterlife of the occupations and movements of the squares, with the exception of Gezi which happened in 2013. Some participants answered collectively with others who had participated in the same occupations. Not all participants answered all the questions, so if a country is missing an answer, this is intentional. Although this special issue takes as its 
main focus anti-austerity protests in Europe, we felt that opening up the questionnaire beyond the European context would allow us to learn more about commonalities and differences between contexts and to provoke new lines of enquiry for thinking about social movement research and praxis. For various reasons (ranging from security concerns to not wanting to claim representation of a movement), some of our contributors have remained anonymous or have used only their first name. All were direct active participants in the occupation movements they are discussing. In the first section, each set of questions is answered in turn by our contributors in Egypt, Portugal, Spain, Turkey and the USA.

In Egypt, Hoda Elsadda an academic and activist, discusses the Tahrir Square occupation in Cairo 2011. In Portugal Luhuna Carvalho, an editor, reflects on the Lisbon Rossio Square Occupation of 2011.

In Spain, Patricia Horrillo, a freelance journalist and guerrilla communication practitioner, and Silvia Nanclares, a writer and activist, reflect on 15-M's Acamapda Sol in Madrid 2011. In Turkey, Çiğdem, a journalist and activist, reflects on the dynamics and legacy of the Taksim Gezi park occupations in 2013. In the USA, a group of anonymous participants in Occupy Wall Street reflect collectively about that experience (available in our open access online version).

Following the roundtable Stavros Stavrides, an architect and professor contributes a reflective piece that responds in a more global way to the questionnaire but through the lens of the Greek Syntagma experience.

Finally, given how influential Tahrir has been for so many of the movements of the squares around the world, and given the backward as well as forward outlook that inspired us, it seems especially fitting to end as we began, with another contribution from Egypt, by the writer, editor and translator Wiam El-Tamami. Her piece, written in Cairo as a result of conversations with two of her fellow participants in Tahrir, has provoked us to consider

SOCIAL MOVEMENT STUDIES, Online Supplement, Fernández-Savater \& Flesher Fominaya (2016) 'Life After the Squares', available at: www.tandfonline.com/toc/csms20/16/1 
how the very questions we ask are shaped by the context and realities of the movements we live in. It also brings to bear the costs, in human life, of standing against brutality and repression and for dignity and justice. Her contribution, written in an epistolary voice, mirrors the intimacy that reflects the space for discussion of anything political in Cairo today, where the space available even for discussion of the political has closed, and is reduced to the space between family (sometimes) and close friends.

Together, this chorus of voices from and beyond the squares offers a chance to reflect on what connects us and what still separates us across the time and space of this global wave of protests. What shines through is that the experience has left no one unchanged, and that it makes sense to pose questions about what happens to individuals, movements, the wider political and cultural context, and life itself, "after the squares".

\section{Section 1: Question and Answer Session}

\section{Life After The Squares}

Is the legacy of the squares still alive, and if so, how?

What has happened to the plethora of initiatives that were born in the squares? Are they still alive and kicking? Have they disappeared?

\section{Egypt/Tahrir (Hoda):}

While the energy for mobilization, activism and protests in squares has subsided almost completely, the legacy of the squares is vivid and alive in the minds and hearts of all who took part, be it physically or virtually. The 18 mythical days, between the $25^{\text {th }}$ of January 2011 and the $11^{\text {th }}$ of February 2011 (i.e. between the start of protests and the day Mubarak 
stepped down) are inscribed in our imagination and continue to be remembered with nostalgia and longing. Needless to say, this is not the narrative of all Egyptians, (there is no such thing as one narrative for sure) but it is certainly the narrative of many Egyptians who were inspired by the revolutionary wave and who dreamed of better and more just futures.

The legacy of the squares is not limited to the imagination but is also manifest in social, cultural and political spheres. On the social level, life in the square, on a metaphoric level, resulted in the formation of new networks, new friendships, new alliances, while refiguring or reshuffling existing ones. To put it simply, people made new friends and lost old ones; relationships, even amongst members of the same family were redefined; sons and daughters rebelled against their parents and accused them of political conservatism; some women joined protests while their partners stayed at home; daughters of wealthy businessmen joined protesters and demanded a more just distribution of wealth; business tycoons with huge investments in power structures found themselves amongst protesters. This was the case as new variables, political and ethical, became key in our evaluation of our place in the world, of our relationships, of our definition of right and wrong, good and bad. This reshuffling of networks and relationships based on life in the squares continues despite the dispersal of the squares and is laden with promises and potential.

On the political level, numerous initiatives emerged: new political parties, new pressure groups, new organizations both formal and informal. Many of these initiatives have either died or were disbanded. Most political parties formed post 2011 have not managed to consolidate their networks: many disbanded and some are still struggling to gain legitimacy and following. The energy and enthusiasm that pushed them to the forefront of political life in 2011 has largely disappeared, mainly due to the hostile environment and the smear campaign orchestrated against political parties and the agents for change by the old oligarchy who led a text-book counter revolution. What is clear now in 2016 is that the 
political environment is not conducive to the creation of strong parties that can seriously compete for power in the polls because the current ruling elite are diligently closing down the political spaces that opened up in 2011, hence making it close to impossible to organize and mobilize.

On the cultural level, numerous initiatives flourished post-2011. These persisted for a bit longer compared to political initiatives.

\section{Portugal/Rossio (Luhuna):}

The "squares movement" in Portugal was comprised of the occupation of the Rossio square for three weeks in 2011. From it came an informal network that structured the anti-austerity movement that lasted until 2013. In relation to other "squares" this movement was particular, as it didn't build on a previous network of social, countercultural or political movements. These movements existed, but not on an organized or tangible scale capable of giving an infrastructural substance to the occupations, which then fell into mere reproduction of the "popular assemblies".

The period's legacy is twofold. On the one hand the momentum gathered in the occupied square, and the activist networks formed within, gave a structure to the period of huge antiausterity demonstrations that followed. The "squares" movement had a complex relationship with the institutional left and these mobilizations against austerity were eventually coopted by the political parties or by the groups who aspired to become the new political parties. The content of the demonstrations turned from a blatant refusal of austerity without specific demands into something instrumentalized towards reclaiming new elections and hence the victory of a hypothetical "unified left". On the other hand several of the links and structures forged in the squares and in the demonstration gained some autonomy from their original placement. Several social centers, collectives and projects

SOCIAL MOVEMENT STUDIES, Online Supplement, Fernández-Savater \& Flesher Fominaya (2016) 'Life After the Squares', available at: www.tandfonline.com/toc/csms20/16/1 
popped up, creating the basis for a burgeoning network of autonomous spaces, practices and movements.

\section{Spain/15-M Puerta del Sol (Silvia and Patricia):}

It's a fact that today the presence in the streets and the number of protests has diminished. On one side, due to a certain wearing down (that level of implication was at an untenable point), on the other, due to "specialization", for example, the entrance into political institutions of new parties and electioneering platforms has made many activists change the environment of struggle or even the focus, taken towards determined battles like those taken forward by the cells of the PAH, (Platform for those Affected by Mortgages ${ }^{2}$ ) focused on the right to a home. Despite these factors, there is still a revitalized citizen network that has not stopped growing and diversifying.

The system's backstage has been left out in the open and the perception of it will never be the same, at least not to a great part of society. It's been like growing up in the "era of the political". As of today, structures created during the weeks of the camp, like the Madrid 15-M newspaper, Ágora Sol Radio or 15 Mpedia, keep working and demanding the struggle of citizens also outside of national and autonomous governments. New projects have been created, as well as new socialization spaces, both in networks and in cities and towns, many times ephemeral but with the capacity to provide a bunch of new ways to do things, to think, to express ourselves, to understand the city and social relations... All of this is alive in collectives of very diverse nature, with a similar spirit to that related to the care of that which is close to home, local neighborhood networks, collective spaces, and the demand for common spaces.

What happened after the end of the camp at Puerta Del Sol is described by many of us as the transformation of the spirit of $15 \mathrm{M}$ into a sort of "virus". That virus was spreading despite the system's defense mechanisms, in charge of demonizing any attitude questioning 
it at any cost. However, the crisis itself enabled a great number of people to see a crude reality in which the lack of employment was causing havoc in a generation that we believed to have a solid future. That awareness, that capacity to see the other despite the masses, that need to feel accompanied and recognize one another in a collective search for a change of model in which the citizens have a central role are the different legacies of the plazas. And like every good virus, it hasn't stopped mutating and becoming more resilient each time.

\section{USA/OWS (Anonymous):}

Though the Occupy movement itself has survived only in small urban groups, the cultural effects of the movement in the US have been profound. We see this in the Bernie Sanders phenomenon, in the intensified discussion of income inequality in the mainstream press, and in the organizational strategies of the recent Black Lives Matter movement. As of this writing, more than half of all young people in the United States trust socialism more than capitalism. This was unthinkable before 2011.

\section{Turkey/Gezi (Çiğdem):}

Gezi is a public park in Taksim square. An urban plan was prepared to build a shopping mall at the park. A group has been protesting this plan since 2012 and on the 27th May 2013 the construction company started cutting the trees and an urgent call was made to defend the park. The police attacked the peaceful protests in a brutal way which caused thousands of people joining the protests. The park was occupied and the movement went beyond the park defence and became an uprising against the authoritarian government in Turkey and spread to other cities. Gezi was raided by the police on the 15th of June and the Park was emptied but the uprising went on in different places and lastly evolved into forums. The movement had several demands: Ending the authoritarian regime, right to 
freedom of expression, ending the police violence and the preservation of the Park were the main demands.

Gezi represents an old and ongoing legacy with its roots in the past. It is now one of the most important references. Although the definition of the square movement is still ambiguous, the key terms are uprising, struggle and possibility. During Gezi's last days, Daft Punk released one of its hit songs, "Get Lucky". A friend cited the lyrics of the song for Gezi: "We've come too far / to give up who we are / So let's raise the bar". This is still relevant. And as I've said before although the people have taken different paths, Gezi is still a very strong reference for everybody.

I'm not quite sure if an abundance of initiatives were born right at the squares. Especially in Istanbul the people who occupied Gezi in the first place were the people coming from different political struggles and movements. Before Gezi, just in one day, - there were many demonstrations - although some of them had no more 100 people - on Istiklal street (a famous street nearby Gezi Park), from Saturday People (protesting unsolved disappearances, mostly mothers) who have gathered there every Saturday since 1995 , to the solidarity marches for journalists who were fired because of joining the Press Workers' Union. And also the $8^{\text {th }}$ of March, $1^{\text {st }}$ of May, Pride March were and are celebrated with thousands of people. So all these people are still fighting.

Amongst the components of Gezi, feminists, LGBTI movement and the Anticapitalist Muslims were on the frontlines and were very effective. Without any doubt they became empowered during Gezi. And another component to be mentioned is the "white collar" worker. As Michael Hardt puts it in the article he wrote following time spent in Istanbul a year after Gezi, white collar workers managed to shift the definition of the working class:

'Finally, the composition of the Gezi encampment and the post-Gezi movement should be read in terms of labor. It is striking how uniformly Gezi militants describe the class 
position of those most active in the movement as "white collar" (beyaz yaka): urban, young, and highly educated, but often poorly paid and precariously employed. I interpret "white collar" here to refer to a cross between the alienated bureaucracy workers that $\mathrm{C}$. Wright Mills named by the term in the 1950s and the newly emerged cognitariat. Activists commonly insist, for example, "we're not middle class, we are workers - white collar workers." A revealing reference of white collar life during the protests, repeated to me more than once, is the film "Fight Club": a dual life, dressed for office work during the day and fighting the cops at night. One of the positive results of Gezi has certainly been to advance the understanding of contemporary class composition, reconsidering the nature of the working class in light of such newly expanding labor categories.' 3

A few weeks before the first anniversary of Gezi the Soma Mine Disaster (where 301 miners were killed in a workplace murder) occurred and the protestors were mainly white collar workers who were "enlightened" at Gezi. The park forums formed after Gezi also evolved into neighbourhood solidarity groups (but unfortunately not on a big scale) like İstanbul City Defence that is fighting against the big anti-ecological projects such as Third Bridge, Third Airport etc. This struggle is directly linked to the Gezi uprising.

\section{Achievements, Effects and Victories}

What have been the effects, achievements and victories of the movements in the squares? What have they managed to change?

\section{Egypt/Tahrir (Hoda):}

Movements in the squares have had two lasting impacts. First, we witnessed an unprecedented politicization of large sections of the population, notwithstanding the political narrative they subscribe to. To explain, we now have two distinct and opposing 
narratives of what happened in 2011: a pro-revolution narrative which posits that 2011 was a revolutionary wave that swept Egypt and the Arab world for a dream of better futures, but was halted or defeated; and an anti-revolution narrative which sees the movement of the squares as a conspiracy from day one with the sole aim of decimating the state and making it an easy prey to its foreign adversaries. The pro-revolution camp has definitely been politicized, and, while many of its members are disillusioned or defeated, they are aware of the potential and the possibilities that were inconceivable before. The antirevolution camp, while they are not critical of the direction of the state, and in fact tend to support anything and everything, are nevertheless paying attention and noting down failures of the current ruling elite in delivering on the promises made. Gone is the political apathy we used to complain about pre-2011.

Second, the opening up of political spaces in 2011 has enabled serious discussions of diverse social and political issues that were previously classified as taboo topics. For example, Muslim/Christian tensions were acknowledged and addressed in a manner that was not possible previously. The constitution endorsed in 2014 committed the state to issuing a law to regulate the building of churches, hence ending an old grievance (a directive dating back to 1856 that imposed discriminatory restrictions on building churches in Egypt) that marred Muslim/Christian relations. Another important achievement made due to the opening up of political spaces is the law passed in June 2014 criminalizing sexual harassment. This was another taboo topic that was swept under the carpet for decades but was finally addressed and discussed seriously in public in the aftermath of the violent attacks against women post 2011.

\section{Portugal/Rossio (Luhuna):}

The Rossio occupation became the grounding event for different attempts of understanding and doing politics. While it's forms and accomplishments were limited, there was a definite 
rupture with the idea of politics being equal to representation and participation. While some of this transpired into the practices we mentioned before, a proper debate about the dynamics of occupation is yet to be had, as they are understood mostly as moments of formal discussion (the assemblies) and not of proper occupation of the space with different forms of life.

It could be argued that some of the groundwork for the agreement between the different political parties of the left who now govern Portugal happened during the period of social upheaval that was, to a point, driven by the social movements. It's biggest victory was, nonetheless, the emergence of metropolitan structures of resistance, however embryonic. While shying away from the spotlight in the last few years, these structures seem to be gaining some consistency which might come to prove interesting, especially when the participation of the institutional left in a government agreement matures into their eventual abandonment of protest politics.

\section{Spain/15-M Puerta del Sol (Silvia and Patricia):}

There has been a double consequence in political and social terms: on one hand, the "exemplary" Transition has been put in question after over 30 years and a critical analysis has been developed in respect to what was put on board and what was covered in the process; on the other hand, there has been the need to create party structures at different levels to get institutions on board and change the system from the inside. With major or minor success, the political landscape has changed in a way that seemed impossible during 2011.

Another important victory could be that of taking charge of the discourse, the change of conversation, a change of attitude that can be measured in very many areas, for five years now politics have been discussed everywhere, although that has also passed through the spectacularization and "tertulia" (political talk show) form of all the debates. Now you 
hear on the radio and on TV things that were only imaginable in activist assemblies or intellectual debates. It's been a mix of effervescence created by the collision between common sense and political formation.

15-M acted as a sort of gasoline for social mobilization and for the emergence of somewhat new forms of parties that manage to put the system of 78 into crisis, and we still don't know if it'll be a defeat or a victory (not just in the ballot boxes but in culture, in lifestyles). Even so, there are many small victories: stopping evictions, occupying spaces like social centers, halting the processes of privatizing healthcare (e.g. Hospital De La Princesa), activating the neighborhood networks, the social fabric of people that were not in the activist scene (older citizens, younger citizens, even kids!)... These milestones or realities have given strength to enable many other things to happen, for instance, stopping the retrograde reform of the abortion law.

\section{USA/OWS (Anonymous):}

They changed the narrative about economics and politics. In a country in which the mainstream media and politicians have traditionally spoken about improving the lives of the "middle class," Occupy made people aware of another way of speaking about society, well-being, and economic distribution. They helped to activate collective memories about postwar social movements in the United States (Civil Rights, feminism, anti-war, etc.), and they provided a language for talking about economic justice as a social issue and not just a question of government policy.

\section{Turkey/Gezi (Çiğdem):}

For Turkey the first thing that Gezi has changed is the ordinary people's relationship with the mainstream media. The media conglomerates still have power but now the people are more sceptical. Lastly what has happened in the Kurdish cities haven't created a big 
response in the Western part of Turkey and the mainstream media still doesn't cover the clashes, the war going on there, but most of the people are more sceptical. ${ }^{4}$ The death of soldiers and guerrillas are being questioned.

And the shift in the definition of the working class that I mentioned in the previous answer had led to some of the freelancer workers' admission in the union. For example the Press Union is admitting freelance journalists, translators. This is a small example but a very important achievement for the precariat. And of course one of the main achievements for Gezi was that the shopping mall project was cancelled and the park is saved until now.

\section{Seeds and shoots: key ideas and practices}

Which characteristics of these movements do you think are the most important and provide the most potential for the future of transformative politics?

One of the most famous phrases from the Egyptian movement was "we know the way back to Tahrir". With this in mind, which elements of these movements do you think can be reactivated? What kind of practices and knowledges can be revived in the future (even if now they might be 'frozen')?

\section{Egypt/Tahrir (Hoda):}

The movement of Tahrir square has resulted in rethinking the effectiveness of representative democracy. Mass mobilization and street politics became the preferred venues for political expression. Ordinary citizens regained confidence in their agency and ability to influence the direction of state politics. "We know the way back to Tahrir" remains an inspiration for many, and the nightmare of ruling regimes. 
The movement has also led to a re-ordering of alliances and networks that transcended class, religious affiliation and ideologies. It was possible for people with very different interests or stakes to get together and work towards a specific goal.

Finally, the movement has redefined the image and profile of the protester. The conventional wisdom in Egypt portrayed the protester/agitator/ rioter as poor, working class and marginalized. The movement of Tahrir nullified this image and propagated a much more complicated and diverse profile.

All of the above characteristics provide potential for a more creative and out of the box thinking of the future of politics.

\section{Portugal/Rossio (Luhuna):}

Given some social specificities of the city of Lisbon - its fairly empty center and its aging population - the squares movement represented a rediscovery of the urban landscape as a political territory, with material dimensions absent from representative politics. This material, territorial and infrastructural dimension seems to be the emerging lesson from the squares movement now that the dust has settled. The relationships and bonds formed during the occupation and the ensuing demonstrations were quite strong for a while, but time takes its toll and the austerity measures forced many people to leave the country, which broke a lot of the ties that were built before.

There have numerous attempts to recreate the squares - to "find our way back" as you put it - but these have been unsuccessful - you might know your way to the river, but you can't dive in the same river twice. A proper and distanced reflection on what happened in the squares should try to distinguish its central elements, which more often than not aren't the most obvious. What made thousands of people (or hundreds, in the Rossio square) join the occupations wasn't merely the reactivation of militant or voluntaristic streaks of public 
participation, but rather something different, which probably can't be reactivated by pure will and activism alone.

\section{Spain/15-M Puerta del Sol (Silvia and Patricia):}

Many of us have noticed in this process that the deactivation of neighborhood movements during the 80s under the government of the PSOE has been in part what has caused us to live in a society that does not believe in parties. The battle and demand in the streets and plazas, the achievement of rights and public spaces, should not subject to the urgency of the present moment. To delegate to the government that which pertains to us and to leave it in the hands of political representatives, be they whoever they may be, implies that we would not be taking responsibility for our present or our future. This crisis should help us reconfigure our lives' priorities and put the defense of the collective at the center of them, in the construction of a system based on the people and not economic growth or competition.

There are lessons that remain from those days and plazas that appear now in the discursive plane of political parties: a commitment to transparency or the search for the participation of the populace in more open processes represent achievements, although many use these ideas simply as marketing. Upon being forced to "modernize" and acquire new commitments with the populace, the parties have incorporated elements into their programs that break away from the opacity of their structures. This hack will not be immediate but it sets forth the process of change that has no turning back.

The assembly form as a "natural" practice of politics. In future, at least between the people who experienced $15 \mathrm{M}$ directly in the Plaza (probably a minority that does not explain, in itself, the movement) political organization necessarily takes the form of "putting together an assembly". It would also be interesting to reconsider how to include the immigrant

SOCIAL MOVEMENT STUDIES, Online Supplement, Fernández-Savater \& Flesher Fominaya (2016) 'Life After the Squares', available at: www.tandfonline.com/toc/csms20/16/1 
population or the younger people in protest, those who have little by little been distancing themselves from mobilization.

\section{USA/OWS (Anonymous):}

The principle of self-organization, the idea that the squares allow everyone to have a voice in the resolution of collective problems, the do-it-yourself (or do-it-with-others) practice of creating structures without waiting for institutions, government, NGO's, etc.

Spaces characterized by their accessibility and liminality. The square was a place open to everyone. Interestingly, Zuccotti Park didn't have a history of activism and protest (unlike Union Square or Washington Square), and this change made it more relevant, started a new conversation. In the square things weren't fixed, like in our workspaces or communities; things were more open.

\section{Turkey/Gezi (Çiğdem):}

For Gezi, [the key characteristic that provides the most future potential is] autonomy, I'd say. We experienced nearly two weeks without "the state". And as I've mentioned in one of the previous answers uprising, struggle and possibility are the key terms. And "memory" should not be forgotten. But not a nostalgic memory, a political memory, with demands for a better future.

During Gezi one of the most important things was the fact that people had their voices heard equally. The uses of language were beyond daily life. Gezi showed that language doesn't only serve for communication, it also serves for transformation. And the ears were open too.

Regarding the power of language there are certain examples, one is: Istanbul Municipality adopted the most famous slogan of Gezi "Her yer Taksim her yer direniş" (Everywhere Taksim, everywhere resistance) for the new metro line's ads and transformed it into "Her 
yer metro here yere metro" (Everywhere metro, metro to everywhere). This exemplifies how vulnerable the municipality is. And the corporations are not exempt to this. They adopt Gezi's words too.

With a live political and collective memory [practices and knowledges] can come back any time. In Turkey a recent uprising at the Blacksea region in Artvin's Cerattepe is a good example for this. ${ }^{5}$ The Gezi uprising was a perfect example of Lefebvre's "right to the city" and of course has influenced and is still influencing other struggles in the country. And we are experiencing Nuit Debout in France right now, we certainly need more Nuit Debout!

\section{Cultural Creation}

The movements of the squares generated an explosion of creativity and cultural production. What effect did this explosion of creativity have in the wider cultural sphere (in terms of creativity, expression, and cultural production)?

At times political action becomes extremely difficult or impossible (blocked by repression, criminalization, etc.), and culture (the cultural sphere) becomes a "continuation of politics by other means". Is there an element of this in your context and how would you evaluate it?

\section{Egypt/Tahrir (Hoda):}

There was certainly an explosion of cultural creation in 2011 and after. New cultural expressions reflected the momentum and energy, spread hope and inspiration, and became the memory of the movement. Three examples:

First, the art of graffiti flourished and became a key form of artistic expression of the revolution. It narrated the story of the revolution, its aims and hopes, its successes, its setbacks. Graffiti is street art, representing street politics, the new form of engaging with the political that has been a hallmark of the Arab revolutions. Graffiti is accessible,

SOCIAL MOVEMENT STUDIES, Online Supplement, Fernández-Savater \& Flesher Fominaya (2016) 'Life After the Squares', available at: www.tandfonline.com/toc/csms20/16/1 
immediate, engaging, communal. It is an open access archive that allows for interactive participation, a dynamic process that captures the dynamism of revolutionary processes. Graffiti on the walls told the stories that are left out of official history. It commemorated the memory of martyrs, young men and women who lost their lives. It gave them names and faces. The most famous graffiti art was inscribed on the walls of Mohamed Mahmoud Street, ${ }^{6}$ the location of violent battles over the past two years. Graffiti art became the site of struggle. In September 2012, city workers white washed the Mohamed Mahmoud graffiti supervised by the police. Almost instantly, graffiti artists and protesters gathered and repainted the walls with more defiant pictures.

Second, one of the most fascinating creative expressions of the spirit and collective psyche of the revolution is the Choir Project. This was a collective effort where young men and women discussed topical issues, wrote songs about them together, put them to music, then sung them as a choir in public performances. Their songs captured the pulse of events and narrated the events from the point of view of young participants in the movements. The songs of the choir record and capture the key issues, key events and the changes in mood and outlook that Egyptians have witnessed post $2011 .^{7}$

Third, Al-Bernameg, a political satire show presented by Bassem Youssef and modeled on the John Stewart's Daily Show, was launched in 2011 and gained enormous popularity in Egypt and the Arab world. It was halted at the end of $2013 .^{8}$

Now the three examples mentioned above are no longer possible. Bassem Youssef's political satire was no longer tolerated. The Choir project ceased with the closing down of political spaces that encourage freedom of expression and collective efforts. Graffiti artists are no longer able to practice their art as they risk arrest and harsh prison sentences. Recently, popular progressive arts centers have been shut down. Nevertheless, it is certainly true that cultural activities can and have become politics by other means. This was the case pre 2011 and is the case now.

SOCIAL MOVEMENT STUDIES, Online Supplement, Fernández-Savater \& Flesher Fominaya (2016) 'Life After the Squares', available at: www.tandfonline.com/toc/csms20/16/1 20 


\section{Portugal/Rossio (Luhuna):}

Some of the work and discussion groups that took place during the Rossio occupation were indeed specifically concerned with cultural and artistic production. On more general terms the broad sense of public intervention did come to influence some of the vocal work of some local artists, but from our point of view these remained within the scope of a limited understanding of politics that didn't take into account the possibilities rehearsed in the squares. Unlike that specific occupation moment that postulated an emerging subjectivity these artworks (I'm thinking of street artist +- or film director Miguel Gomes, whose "1001 nights" aimed to portray the country during austerity) took politics back to a series of demands made to a sovereign power and critique back to a merely moral denouncement of the ruling class.

While it is true that a politics that is contained might find expression in artistic production it is also true that the material conditions of the production of art (and artists) may act as a first deterrent towards making a political art. More than a blocking of politics that is unblocked by art I would like to think that the small rebellious moments we saw in Lisbon were the unblocking of art by means of radical politics.

\section{Spain/15-M Puerta del Sol (Silvia and Patricia):}

It's true that as comedian Ignatius Farray said, politics is the new rock ' $n$ roll. In these five years, there has been a very harsh criticism of previous phases of our cultural history (the 90s, the 2000s) as periods in which culture was completely outside (in many aspects) of cultural discourse. As a reaction, a bunch of artists (from Nacho Vega to Amaral) have impregnated their lyrics and their ways of being with what was happening on the street. Filmmakers and writers have given voice to the conflicts that were happening outside. And those who haven't, have felt interpellated.

SOCIAL MOVEMENT STUDIES, Online Supplement, Fernández-Savater \& Flesher Fominaya (2016) 'Life After the Squares', available at: www.tandfonline.com/toc/csms20/16/1 
But it is also true, that from the point of the mobilization, the cultural battle has remained very much in the level of the sectorial battle and it seems to have opened few relevant veins (at least, within what is mainstream). The artistic establishment has limited itself to summing up to the politicization in very reformist demands such as the lowering of the VAT. Although it is also true that there have been labor battles against precarization (we are thinking of the technicians of public theaters) of cultural labor (in many cases autoprecarization in the case of the precariat), it seems like culture as an estate has seen itself a bit more receptive, even if it finds itself in the centre of criticism towards the Culture of Transition. Being "progressive" has become an exercise even more difficult to strengthen.

On that note, another difficult battle is taking place in the implementation of public politics and programs that allow a transfer of what Luis Moreno Caballud calls "anybody's cultures" which was iconic in 15-M. Milestones like the Cabalgata de Reyes in Madrid, the Carnivals or the Law of Historical Memory (to speak of the case of the City Council of Madrid, which is the most well known), show us how culture is a very productive battlefield in which to construct tales that benefit existing power holders (that goes far beyond the number of council members). That way, popular culture positions itself all of a sudden in the line of sight of those who wish to continue perpetuating a state of affairs which benefits those higher up the ladder.

In another order of things, but also a part of culture, we have lived through a process of savage desacralization within political communication. Humor as a cultural creation and tool of political transmission has made itself a constant with no way back. And something so rooted in the base of the movement seems essential to us, which is to choose a culture of peace and democracy in response to the violence of funding cuts and the precariousness of the state of living, in place of a fear or hatred response which is being given by other countries in which clearly xenophobic parties are growing in numbers. 


\section{USA/OWS (Anonymous):}

Representations of financial crisis and income inequality are everywhere in the US cultural sphere-from films and TV shows (e.g. The Big Short) to poetry (e.g. Commune Editions). But the relationship between these representations and the actual transformation of daily life are by no means clear. In fact, the most visible artistic works about Occupy and the financial crisis remain highly dependent on preexisting cultural institutions and economic structures. In the US, with some exceptions, Occupy was not able to create an alternative (sustainable) cultural system.

\section{Turkey/Gezi (Çiğdem):}

Explosion of creativity was there long before and instead of naming it as a result of Gezi, I'd say it was one of the causes. And also humour has been a very important part of the uprising in Turkey. There were great examples of culture jamming. This is also due to the fact that an important part of the people who occupied the square are fervent humour magazine readers. Humour magazines in Turkey are important alternative and independent media and they sell sometimes even more than the other media. Looking at the cultural sphere in Turkey after Gezi, the movement is there as a very strong reference, maybe not always directly but rather in a "cool" way.

Cultural production itself is a political action too. What happened three years ago here and there, in all other countries was also a very strong reaffirmation of Jean Paul Sartre's ideas. And looking at Istanbul Gezi example, artists have been a very important part of this movement.

SOCIAL MOVEMENT STUDIES, Online Supplement, Fernández-Savater \& Flesher Fominaya (2016) 'Life After the Squares', available at: www.tandfonline.com/toc/csms20/16/1 


\section{Forms of Life}

Revolutions, insurrections, and uprisings never only produce legal, political or institutional changes, but also affect our most intimate relations and create new forms of life. How does the new politicization that was born in the squares manifest itself in conversations, behaviors and intimacy? What changes have been produced in sensibilities, common sense, emotions and affect?

\section{Portugal/Rossio (Luhuna):}

The square, or its epoch, generated its fair share of different political millieus and the preliminary sketch of a coming subjectivity. The occupation was contemporary to a return of young people to the city center, which made easier the continuation of the relationships produced in the squares and the demonstrations. This common subjectivation was also informed by the dynamics of crisis and austerity, which were more or less felt by everybody. This translated into the opening of a few social centers, canteens and meeting spaces, as well as the multiplication of affinity groups. It is however debatable how much these forms of life depart from the phenomenology of contemporary socialization. Groups turn into cliques, resistance into subculture, and movements into millieus.

While moments such as the squares might function as a social catalyst they can't function as an arché, a mythical foundation. Communities and forms-of-life are always reproducing through what they live and experience, and if struggle is absent then they wither away into something else.

SOCIAL MOVEMENT STUDIES, Online Supplement, Fernández-Savater \& Flesher Fominaya (2016) 'Life After the Squares', available at: www.tandfonline.com/toc/csms20/16/1 24 


\section{Spain/15-M Puerta del Sol (Silvia and Patricia):}

We distinguish between Plaza and movement. From the point of view of the people who lived the plazas or more intensely lived the movement, this supposed that "their lives would change". What is key is: making politics include many people who had never been involved with it before that point, with all that involves regarding personality, time distribution, personal relations (new friends and leaving behind friendships with others), etc. Some people radicalized this, experimenting with life in the margins (for example evictees who began to occupy, people who began to participate in social centers or "good citizens" who lived through difficult judicial processes, which implies/involves a very strong change in subjectivity, although not always a visible one.

Widening the frame to people who didn't experience the plazas because they weren't there, due to their town or city not having a notable movement or featuring purely old movements, there can be more doubts that the movement brought a change to sensitivity, common sense or the emotions or affect.

Lastly, living the movement through communication platforms, such as how they are used and work in Spain, involved acceptance through a not-very-political sentimentality. We are thinking here, for example, about the "eviction drama" that has competed with - but without being able to defeat - the narrative of individual responsibility involving personal debt.

\section{USA/OWS (Anonymous):}

We think there was a moment of dissonance, a moment in which people stop believing in the mainstream narrative. A kind of moment when everything collapses, and people feel that they need to speak. Also a kind of moment like "the emperor has no clothes", when it was revealed that the government is not acting for us anymore, its not taking care of the population - they cut public funding to give it to the corporations, to global trade. 


\section{Turkey/Gezi (Çiğdem):}

We were threatened all together and we fought back. People were killed during the uprising. Although we didn't know them personally their loss had a very deep effect on us.

\section{Normalization}

By which means has the potential of these movements and new forms of politics been deactivated or attempted to be deactivated?

In your context has there been an authoritarian counter-revolution? Is this taking place by traditional repressive means or via new forms of repression?

Has this fear been reintroduced into societies that have managed to free themselves offear for a moment in time? Has it been successfully re-implanted in society? Do you think people's lives in general have returned to "normality"?

\section{Egypt/Tahrir (Hoda):}

Now, in 2016, we are experiencing a full-fledged counter-revolution. Ousted president Mubarak has been released having completed a three-year sentence on corruption charges. He was not formally charged with murdering protesters in 2011 nor was he held responsible for the deterioration of the country. Though technically a free man, he now resides in a hospital room that is guarded and secured by the military police, in what is seen as an agreement with the army to avoid causing agitation and discontent. His two sons have also been released: Gamal who was groomed to be his successor, and Alaa, the businessman. Most of the old regime cronies have been let off the hook, pronounced not guilty by the courts. The remaining Mubarak affiliates are currently negotiating reconciliation deals with the courts where they will pay money in return for dropping charges against them. At the same time, the faces and names of the young men and women at the forefront of the $25^{\text {th }}$

SOCIAL MOVEMENT STUDIES, Online Supplement, Fernández-Savater \& Flesher Fominaya (2016) 'Life After the Squares', available at: www.tandfonline.com/toc/csms20/16/1 
of January revolution are behind bars serving sentences based on trumped up charges and extraordinary legal procedures. The list is long and heart breaking.

In effect, street activism has almost died. The barrier of fear that was broken in 2011 is now officially back. Joining protests that defy state policies now is almost suicidal as the police have a license to shoot to kill with impunity, and mass indiscriminate arrests lead to harsh sentences. The smallest sit-in can, and has been, dispersed with maximum brutal force. However, labor protests have continued in the form of sit-ins, marches, and strikes. They are primarily linked to wage disputes and punitive dismissals. In the first half of 2014, the Mahrousa Center for Socioeconomic Development counted 1,651 labor protests. In 2015, the Democracy Meter documented 1.117 labor protests ${ }^{9}$. Most recently, on the $15^{\text {th }}$ of April 2016, thousands took to the streets to protest against the signing off of two islands, Tiran and Sanafir, to Saudi Arabia, a decision made by the current government and considered by many as an unconstitutional act of forfeiting Egyptian sovereignty. Another protest was called for on the $25^{\text {th }}$ of April, an official holiday commemorating the withdrawal of Israeli forces from the Sinai Peninsula in 1982. On the day, squares all over Egypt and key urban centers were barricaded by the police, making it impossible for people to congregate. A few hundred managed to march together and were immediately dispersed with tear gas. Many known activists were arrested from their homes before the $25^{\text {th }}$ and a few hundred were arrested on the day. On April 15 2016,115 of the said protesters received harsh prison sentences.

"The old is dead and the new is yet to be born." This has proved to be a very wise statement. We are now living a new normal, but have not yet figured out the rules of the game, or rather, the new normal has not quite sunk in yet. Fear is back, but not quite in the same way because it has not yet been consolidated with apathy. Though many have decided to quit and focus on their private lives, others continue taking an interest and participating in 
public life cautiously; some have regrouped and redirected their interests in safer spaces. Many continue bravely taking huge risks with their lives and their livelihoods.

\section{Portugal/Rossio (Luhuna):}

On an immediate scale the bureaucratic concerns of the institutional left were pivotal in deactivating the movement, and what they couldn't accomplish was carried through by the lack of experience in dealing with repression and reflux of peaks of mobilization. The incapacity of the movement in going beyond the repertoire of classic politics - assembly, meeting, demonstration, demands - made its conquests ephemeral when the cuts started to affect daily life. On a more general level one could perhaps address how austerity itself came to dominate the general political mood as an unavoidable fatality whose only respite would be the general elections that would happen sooner or later.

It could be said that lives went back to normal if we understand normality as a political operation of neutralization. Austerity changed people's lives, their economic relations, their perception of society and power and their understanding of the daily struggle to survive. The defeat of the movement propelled people in the direction of, and not back to, a new normality.

\section{Spain/15-M Puerta del Sol (Silvia and Patricia):}

There was an attempt to criminalize the movement and turn it into something despicable from day one, once trying to make it invisible was no longer possible. When on the dawn of the second night of occupation of the Puerta del Sol, the riot police forcefully removed the people who had peacefully stayed there to speak, it generated the opposite effect. Their violence birthed our peaceful yet forceful activation: camping. However, fear is the tool most used to deactivate society because it's the most effective. Especially in Spain, with a structural fear we've inherited from our grandparents and our parents. That admonition 
"don't stand out" (or "don't tweet" in the $21^{\text {st }}$ century) represents the fear of police repression during Franco's regime which, despite a lack of dictatorship, remains today.

On the streets, there has been and still is police repression. The mere presence of vans and riot police in plenty of pacifist concentrations finds a double function: to identify those who are protesting, to control and subdue them; and to those who are observing from the outside or through social media to get a clear message that protest is something violent and those who do it are dangerous. The so-called 'gag law' is the form in which the government has materialized the criminalization of peaceful protest. The fine on people with few or no income forces us to think twice about whether to support a mobilization in the streets, however legitimate and necessary it may be. It's a new strategy that seeks to keep people in their homes and avoid at all costs that we support one another on the streets.

The other novelty in terms of repression is tied into the previous one: (self)censoring. To make punishable the act of expressing certain thoughts, ideas or, even, artistic manifestations has made a lot of us cease to express freely what we think. Paradigm cases like Guillermo Zapata's black humor tweets or the use of a poster in a puppet show with the text "Gora alkaETA" (a parody of Go ETA or Up with ETA), which precisely denounced the criminalization of the victims of the system, have led to absolutely disproportional methodical and political prosecution against these people, have altered the very concept of freedom of expression.

The debate artificially constructed by the oligarchies (which see their stability as threatened) is more manipulation than ever and having the mass media at their disposal makes it very difficult to break. The discourse focuses its efforts in turning peaceful mobilizations into extremisms, in such a way that right wing parties self-proclaim themselves from the center seeking to demonize those who represent social values. All that's missing is them shouting "The reds are coming!", though the effect of believing the left is dangerous is still at play. Living in a society that's been particularly infantilized (in 
part due to the tiresome and forceful message of the Catholic church), that does not assume responsibility as a political actor from fear of its own freedom, makes it difficult to achieve even deeper change.

There's also something different and, in part, an evolution: now we've found ourselves forced to integrate protest into our daily life. A veil has fallen that cannot be replaced and we no longer perceive crisis as something circumstantial but as something permanent in our lives. We've lost commodity and we've gained class consciousness. We could say that, instead of "we were asleep, we've awakened", "we were peacefully snoring, with drool and all, and we had to wake up."

\section{USA/OWS (Anonymous):}

Many of those who were involved in Occupy have had difficulties sustaining the structures of the movement over the intervening years. Particularly in the New York area (from where we write), it is nearly impossible to earn a living without being part of highly demanding academic institutions or corporate culture. It's expensive just to live in the city, and most people's sources of income are unstable. That's normality.

\section{Turkey/Gezi (Çiğdem):}

For Turkey, the time between two general elections in 2015 and bomb attacks have been attempts to "deactivate" this potential. Two years after Gezi the general elections were held in Turkey and the country had its momentum with the Peoples' Democratic Party (HDP) having roots in the Kurdish political movement. HDP was a result of Gezi and represented hope for a new politics and at the first election in June won 80 seats at the Parliament (out of 550, but there's a threshold of $10 \%$ in Turkey's electoral system) which has been a great success within the context and was a clear result of Gezi. But the AKP (Tayyip Erdoğan's ruling party) managed to repeat the elections a few months later in November with a pretext 
that the June election resulted in a hung parliament. And in the following time the ceasefire negotiations between the PKK and the Turkish state collapsed. These are the main attempts to deactivate the new forms of politics. And lastly the parliament voted a new constitutional amendment that will partly revoke the immunity of the MPs and especially designed to oust the HDP members at the parliament.

Turkey has always been an oppressive country. The pressure continues in both traditional and new forms. But the media is silenced more cruelly than before. According to Freedom House figures regarding press freedom Turkey ranks $156^{\text {th }}$ among 199 countries. ${ }^{10}$ Bomb attacks and war tactics can re-instil fear anytime. This is what happened in most of the places, especially in Syria. In Turkey bomb attacks have caused a general feeling of panic and fear. [People's lives have not returned to normalization.] No, not at all. Syria, Egypt, Greece, Spain, Tunisia, Turkey... For all of these countries these are extraordinary times. People's lives in general haven't returned to "normality", we live in a state of tenseness and uneasiness. In Turkey after the government called off the peace process, the attack to the Kurdish cities and the aftermath is far from normality. Until now there hadn't been a strong response from the Western part of Turkey.

\section{Problems}

Do you think movements like those in the squares have intrinsic limits? What could have been done better? Which kind of problems were unable to be overcome?

Were the great "absences" of these movements (i.e. absence of leaders, absence of structures, absence of programs) strengths or limitations?

How can we think through the problem of the longevity of these movements? Is it possible to invent, beyond the dichotomy bureaucracy/spontaneity, new tools, new forms of

SOCIAL MOVEMENT STUDIES, Online Supplement, Fernández-Savater \& Flesher Fominaya (2016) 'Life After the Squares', available at: www.tandfonline.com/toc/csms20/16/1 
organizations, and new institutions that are capable of sustaining them and extending them in time?

\section{Egypt/Tahrir (Hoda):}

The great "absences" of the movements of squares were certainly points of strength at a particular moment in time. The absence of a leader was key in sidetracking state repression: security forces did not have a name or an address they could clamp down on. It also nurtured ownership of the movement and made its success or failure the responsibility of all involved. The absence of a leader also maximized commitment and dedication. The squares had structures but they were horizontal and non-hierarchical. At a time of turmoil, this was a strength, as it enabled participants to transcend petty squabbles over division of roles or status. The absence of programs, or a specific ideology empowered the movement and allowed for alliances that were impossible to imagine previously. People of all stripes and colours congregated around one goal: the ouster of a dictator to pave the way to a more just social order. The squares became an alternative reality, a wordly utopia that inspired and motivated.

However, some of the strengths were also the movement's Achilles heel. The utopia went to the head of participants and encouraged many to be maximalists and uncompromising. The absence of a trusted leader who could negotiate on behalf of the revolution with power structures, with security apparatuses, who could make the necessary compromises and political deals that had to be made in order to move a step closer to a democratic society, was detrimental to the movement. No such leader existed and anyone who ventured to make a compromise was condemned as a traitor to the revolution. This left the door wide open for political opportunists to strike shady deals that undermined the revolutionary momentum and eventually led to the demise of the revolution. The absence of structures

SOCIAL MOVEMENT STUDIES, Online Supplement, Fernández-Savater \& Flesher Fominaya (2016) 'Life After the Squares', available at: www.tandfonline.com/toc/csms20/16/1 
enabled the only organized group in the country, the Muslim Brotherhood, to win a landslide victory in subsequent elections.

Can we rethink the political? In Egypt, and after the experience of the landslide victory of the Muslim Brotherhood, many questioned the rules that regulate representative democracy and argued that equating democracy with electoral processes was in effect a ballotocracy, that has emptied democratic governance of its meaning and reduced it to technicalities that did not necessarily reflect the will of the population. Many democracies now are in the throes of powerful elites with money.

Can we think of new forms of organization? Of hubs, instead of formal hierarchical institutions, hubs that draw people around an idea, an aim?

\section{Spain/15-M Puerta del Sol (Silvia and Patricia):}

One of the limits of protest is the demand of the protest itself. Who can sustain those levels of implication and commitment that the plazas possessed? In the end, it's a non-dependant subject, healthy and usually young, though one of the big revelations of the past five years have been the Yayo Flautas (but, at the same time, they're retired people, at the end of their productive lives). ${ }^{11}$ Where does that fit in the people with strenuous schedules or people in their care? Another one of the limits can be language, that sometimes becomes endogamic and only appeals to one type of person.

The lack of leaders continues to this day to be one of the great potentials of 15-M since it forced each one of us to represent ourselves. That change of focus (making someone else be the one to stand up for us, to guide us, to tell us...) supposes a change in paradigm regarding the assumption of responsibility. Becoming accustomed to delegate and not being educated in taking charge of our own narration, it becomes tremendously easy to fall back on that search for a leader to trace the lines for us to transit. However, when we renounced that representation (so well expressed in the cry of "they don't represent us"), 
we grew. As individuals and as a collective. A movement without leaders cannot be dethroned or decapitated.

\section{USA/OWS (Anonymous):}

Despite a broad recognition that income inequality has gotten worse and that the neoliberal policies of the American elites have damaged the country, there are few visible alternatives on the horizon. Small experiments in cooperative economies and cultures exist, but whether they will be sustainable remains to be seen.

\section{Turkey/Gezi (Çiğdem):}

The most promising thing that happened after the squares were emptied was the forums. In many different parts of Turkey forums were held in public spaces, parks etc. So this was again a great example of "right to the city". Forums should have found a way to lead to big solidarity demonstrations but they didn't.

With regard to "absences", they had strengthened the movement. But also, the space of these absences were filled by memory. Throughout the occupation all the encouraging leaders, structures and programs of all times were present in a way.

Reinvention is happening again now. Gilles Deleuze and Felix Guattari's (1988) term "Rhizome" explains the situation perfectly. As they put it in A Thousand Plateaus: 'Unlike trees or their roots, the rhizome connects any point to any other point (...) a rhizome may be broken, shattered at a given spot, but it will start up again on one of its old lines, or on new lines'.

SOCIAL MOVEMENT STUDIES, Online Supplement, Fernández-Savater \& Flesher Fominaya (2016) 'Life After the Squares', available at: www.tandfonline.com/toc/csms20/16/1 34 


\section{Representation}

What is the relationship between the squares and political factors that aspire to represent them, express them, or translate them, institutionally or electorally? (Syriza, Podemos, Bernie Sanders, etc.)

What do you think have been the consequences or implications of this electoral phenomenon as far as austerity politics or processes of political mobilization are concerned?

Some of these new parties (for example, Podemos in Spain) present themselves as a hybrid option between party and movement and point to the incorporation of participatory elements such as digital tools or participatory budgets as evidence of this. Do you think that it's possible to combine a party logic and movement logic within the same structure? Is it desirable to do so?

\section{Egypt/Tahrir (Hoda):}

In Egypt, the environment is not conducive to building and consolidating parties. This is the time to think of alternative ways of organizing and mobilizing. We need to think outside the box and imagine new formations, possibly hubs, around which people can congregate and work together.

\section{Portugal/Rossio (Luhuna):}

From the start of the occupation the participation of political parties was a hot issue. On one hand these were contested from people who felt that institutional politics didn't have a place in the occupation, on the other several other organizations looking for a stage felt that their moment under the spotlight would be blocked by the bigger institutions they aimed to replace. These conflicts continued on to the phase of large anti-austerity demonstrations 
that happened between 2011 and 2013. While several platforms called for demonstrations, and while political parties did participate in them, is wasn't until a collective called "que se lixe a troika" (fuck troika) was formed that they managed to gain an upper hand and redirect the general tone of demonstrations from anti-austerity towards a demand for new elections (which failed). This generated a high level of conflict within the general activist millieu that emerged from the occupied Rossio square and in the end it is probably one of the reasons of its demise.

The period between 2013 and the 2015 election was fairly eventless. The elections gave Left Bloc, one of these parties, a record vote, much due to the media protagonism some of their militants had in the months before the election. However this doesn't mean that the party, formally or informally, adopted or even discussed the theoretical and material advancements of the squares. Rather, their inclusion in a government agreement came to further distance the party direction from participatory politics, even from its own militants.

\section{Spain/15-M Puerta del Sol (Silvia and Patricia):}

When we speak of representation we should keep in mind what is spoken of in article 23 of our Constitution: "Citizens have the right to participate in public affairs, directly or through representatives, freely chosen in periodic elections by universal suffrage." The fact that there are new political actors in institutions should not change the desire for participation in the political life of the rest of the people, and we should not forget the fact that direct participation should appear in the first place, preceding representation.

The mistake lies in thinking that a party (whichever it may be) should represent us other than as a tool to enter the system. Because what these people should do when they form part of the institution is represent values with which the majority of the populace can identify. Understanding that democracy can only be articulated through ballot boxes and representation is mutilating the idea of constructing a society through collective means. We

SOCIAL MOVEMENT STUDIES, Online Supplement, Fernández-Savater \& Flesher Fominaya (2016) 'Life After the Squares', available at: www.tandfonline.com/toc/csms20/16/1 
keep believing that politics is that which is done by parties and is shown to us through the media, when in reality politics is everything that we come across in life, which we all must face.

\section{USA/OWS (Anonymous):}

As of this writing, the 2016 US election will almost certainly be between Hillary Clinton and Donald Trump. That sucks. The rise of Bernie Sanders galvanized millions of people in the US--it's estimated that he earned $80 \%$ of the vote among Democrats from 1830. And it seems likely that broad dissatisfaction with the nominees will lead to a broad shakeup of the two-party system in the near future. This will almost certainly present an opportunity for electoral experiments related to the movements of 2011.

At the same time, in electoral politics things work in a different way -you articulate your desire for democracy through donations, volunteering for a campaign... but what happens when the campaign is over? Or even if your candidate or your political party wins, like Syriza, but they cannot fulfill the desires of the people, then what happens? The space for the voice of anyone is not there anymore, not in macro-politics, not even in the physical space...

Instead, in Occupy you could create any working group you wanted, you didn't even have to be in the general assembly; people created spaces for their voice, and then later it became more about bringing that voice to the workplace, to communities, to neighborhoods...

\section{Turkey/Gezi (Çiğdem):}

"Representation" is a tricky term. These political factors have learned a lot from these movements, but of course in every context transformation of this "new politics" is different. In that sense Turkey lived its momentum with the Peoples' Democratic Party (HDP) but 
the institutional system took over again. However Barcelona's mayor, Ada Colau, is a good example of this bridge.

We haven't seen any positive change yet (in electoral terms). The important thing is to transform the politics, so what is needed is a transformation. Combination [between movements and electoral logics] is inevitable and we should keep in mind that still technology is being used in a more efficient way by the institutional bodies. Therefore what matters is ideology and the struggle for dignity.

\section{How to Carry on After the Squares}

After the squares have emptied, and the movements no longer are the center of political energy, how is it possible to carry on without becoming depressed or nostalgic?

If we think about the reality that the movements of the squares were "cooked up" somewhere (there were precursor movements and previous political processes that led to them), are we witnessing the preparation of another wave of movement within the "normality" of this period "after the squares"?

\section{Egypt/Tahrir (Hoda):}

Great expectations often lead to great disappointments. This is certainly the case with many people who saw their hopes mercilessly crushed. In these times, it is important to keep our eyes focused on what has been achieved and to foreground and celebrate all victories no matter how small. The lesson learnt from Tahrir is that the battle for freedom will not be won by a knockout blow but rather by incremental points. 


\section{Portugal/Rossio (Luhuna):}

The demise of movements always seems to presuppose their extinction, however, on a broader scale, we do see temporal and social connections between different moments of political resistance: we see antiglobalization blocking tactics surfacing in Black Lives Matter and Tiannamen in Taksim. The popular theories of understanding late capitalism seem to underline its capacity for total recuperation and yet underground connections and influences can be found and drawn all the time. Perhaps one of the lessons to be drawn from the squares is one where we le learn to understand moments of reflux as important lessons towards political struggle and gain the capacity to detach autonomy and emancipation from merely triumphalist and voluntarist moments.

\section{Spain/15-M Puerta del Sol (Silvia and Patricia):}

We shouldn't forget that the "time after" the squares has been a period of intense work by all of us who believe that the arrival of these institutions does not signify the end of the battle. The potential in 15-M (that transformative and enabling energy) has taken thousands of forms and has led many people to believe in that collective "yes we can" (turned into a mere slogan cannibalized by Podemos), which has broken with the ingrained message, against utopia, that we're socialized into believing since we are little, that "you can't change the world."

We shouldn't lose sight of the streets, the translation of ideas to acts is the path that we must take and which has been set in motion in these times of "dispersion". The distance between discourse and action: how horizontal structures are set in motion, structures of participation, of transparency; how the rupture of the capitalist myth is integrated into daily life - we don't want to be merchandise and we want to set into motion worlds where other realities, like that of social economy, can be legitimate; how to continue to empower neighborhoods; how to keep putting in practice both feminism and care in our daily lives, 
direct action, creativity in actions... and understand that there are two rhythms, always, that which is social and that which is institutional. And there, the populace is always in the lead.

\section{USA/OWS (Anonymous):}

Examples of taking the squares movements to the neighborhoods or workplaces in NYC include the Free University, the Adjunct project at CUNY (oriented to knowledge production)... and other projects, physical spaces like Woodbine in Ridgwood, Queens, Take Back the Bronx social center, Mayday space in Bushwick. Also, Black Lives Matter in Ferguson, in Baltimore, spaces that a lot of people completely ignore are sometimes the ones that bring the strongest challenges to capitalism now, spaces in which people can create their own political identity, without conforming to a previously existing political identity -without worrying about Democratic Party or labor union norms...

Is the logic of the square scalable? It's a challenge - how effective is moving from the square to society as a whole? $-80 \%$ of people from 18 to 30 are voting for Bernie, or don't believe in capitalism: this is not so much the square being scalable, but having a symbolic effect on electoral politics. Does the new institution that we have to create have to be like the square? In what sense?

Scale is not the major problem - we can build horizontal directly democratic organizations and scale them up, but scale is not the most important problem: in the participatory budget in NY people vote for more security cameras, some people love the police in NY, despite BLM protests. We are not at a point in which we can create a new society with the whole of society, organization is needed, not in an authoritarian way, but we are not society, we are not the square, not yet.

At the same time, maybe one important feature of the movements of the squares was that they didn't replicate the activist tendency to self-marginalization, they were in a way "mainstream" - for good and for bad - a lot of people now don't believe in capitalism, they

SOCIAL MOVEMENT STUDIES, Online Supplement, Fernández-Savater \& Flesher Fominaya (2016) 'Life After the Squares', available at: www.tandfonline.com/toc/csms20/16/1 40 
think it's a scam, in this sense we can say that we are the people. We are part of society, we cannot pretend we are out of society, we are enmeshed in it and need to provide alternative ways of doing.

Then, we also have to admit that having a majority of the people mistrusting capitalism is very different from having figured out how to live in a non-capitalist way, this is a problem that we all have.

Movements have to come up with alternatives, demonstrate them -for example, alternatives to the prison industrial complex. In Zucotti we had clinics, different ways of doing things, alternatives.

\section{Turkey/Gezi (Çiğdem):}

Eduardo Galeano quotes in an interview a graffiti he had seen in a street in Bogota: "Let's save pessimism for better times."

Firstly, I don't think "normality" is one of the features of the times we live in. The answer to whether we are witnessing the preparation of another wave of movement is yes for sure, because the struggle never ends. Now we are witnessing Nuit Debout in France and maybe tomorrow we'll hear good news from India. We can turn to Deleuze and Guattari's "Rhizome".

\section{Between Squares}

What did you take from what you witnessed or became aware of happening in other squares? Do you think that other squares could benefit from the experience of your square? Do you have any message for them? 


\section{Egypt/Tahrir (Hoda):}

Tahrir square was an inspiration to many squares. I remember receiving messages of solidarity and support from friends and colleagues all over the world. All talked about being glued to their TV screens and watching closely events as they unfolded. I believe the world was taken by surprise as they watched a country in the Arab world rise against its rulers and demanding bread, freedom and dignity. These demands resonated strongly with $99 \%$ of the world population who are exploited by the $1 \%$ who control most of the wealth and resources. The movements of squares in many countries rendered the struggle global rather than local. Knowledge of other squares was inspirational and empowering. We will win because our fight is just.

\section{Portugal/Rossio (Luhuna):}

Funnily enough, the Portuguese acampada started as an occupation in solidarity with the Spanish Indignados made by Spanish Erasmus students. As much as there was a considerable knowledge about what was happening, the information followed the media description, which stayed away from the organizational and material realities of the squares. Contact often happened following ideological lines of contact, and hence often strayed from strategic and tactical points towards merely ideological agendas. There is however an immediate and unconcealable potency of images that breaks through their ideological packaging and that connects those who feel them rather than just watch them.

\section{Spain/15-M Puerta del Sol (Silvia and Patricia):}

We feel like we have grown. And now we are aware that life is nothing more than a process in which, sometimes by logical resistance to change and others (most common) by fear of what we don't understand, we hold onto a static and unmovable image of ourselves and the reality that surrounds us. Five years after that $15-\mathrm{M}$ we have transformed part of our 
discourse and our way of understanding things. We know that being heard, even from dissent, is necessary to not turn life into a Manichaean and empty battle. We know that feminism and care are pivotal for this capitalist, consumer and individualistic society to change. And it's necessary to break the eminently productive dynamics to pay necessary attention to the reproductive.

15-M went through us and we made ours certain discourses that seduced us, opened our minds and allowed us to situate ourselves on another individual and collective dimension. It helped us mature, to question ourselves and know that we are not alone. We also know that this new map of reality is not unchangeable and it's important it stays that way to keep learning and growing.

\section{USA/OWS (Anonymous):}

In 2011, we witnessed the movement of the movements from country to country. In the US, Black Lives Matter has adopted tactics from the Occupy movement, even as it has more clearly emphasized the racial dimensions of social and economic inequality. In Nuit Debout in France we see a cross-pollination of youth, refugees and labor struggle; almost as if Occupy and Black Live Matters happened at the same time. Also, in Spain we see strong alliances between an impoverished middle class and those who were in a worse situation. The movement in the US has been very influenced by the Arab Spring and the Spanish 15-M, among others, but at the same time it has its own peculiar challenges, particularly, perhaps difficulties in forming solid alliances across class and race.

\section{Turkey/Gezi (Çiğdem):}

Solidarity doesn't have borders but nationalism has. So as long as there's solidarity anything is possible. And we should keep Mark Twain's words in mind, "history doesn't repeat itself but it does rhyme." 


\section{Section 2: Holistic Answers}

Prompted by all of the questions above, the two authors included below presented a more holistic style of answer; their accounts of the years since the uprisings in Greece and in Egypt interweave many of the elements discussed above.

\section{Greece/Syntagma (Stavros Stavrides)}

One of the most important problems connected to the appraisal of the so-called "squares movement" is that, indeed, it encompasses experiences, actions and forms of organization that emerged in societies with different characteristics. Both for activists and for engaged researchers the problem of how far can one go in forming generalizations and in diagnosing overarching tendencies is crucial. What, however, seems to support an effort to see beyond the apparent heterogeneity of those events is the fact that in almost all cases occupied squares referred to each other and recognized shared characteristics.

We cannot, of course, forget that the media (both the dominant ones as well as the ones called social media) directly interfered, selectively highlighting characteristics and labeling behaviors. We have clear indications that in many cases, preceding actions in other countries became sources of inspiration for occupations and similar collective acts. However, descriptions by dominant media often distorted important particular characteristics. For example, although the Syntagma square occupation in Athens was from the beginning referred to by the dominant media as an "indignados" (aganaktismenoi in Greek) movement, most of the people in the square were reluctant in naming themselves so. The word was mostly used in Greece to describe ultra right wing actions disguised as conservative citizens' "ethical fury". We also know that the term "Arab Spring" was

SOCIAL MOVEMENT STUDIES, Online Supplement, Fernández-Savater \& Flesher Fominaya (2016) 'Life After the Squares', available at: www.tandfonline.com/toc/csms20/16/1 
invented by the media which were thus imposing comparisons with the events that lead to the fall of the Eastern block regimes. Naming the squares movement has a performative effect.

What seems to connect these movements both literally as well as in terms of action categorizations is that they were open manifestations of a growing de-legitimization of the corresponding regimes. In the Arab region this meant a direct confrontation with autarchic governments. In the European cities this meant a direct clash with unjust and devastating austerity policies. In the Americas and Asia this meant mostly a direct challenge to established economic oligarchies. In all the cases however, delegitimization seems to have lead to a reclaiming of democracy. We know, of course, that this term is at the center of fierce debates, and that it has become the ideological flagship of the self-proclaimed "free world". Ambiguities and direct contradictions may result (and indeed have resulted) from this pre-history of the term. However, the squares did not simply declare the importance of democracy but explicitly experimented with practices of democracy. This is one of the most important and long-standing legacies of those events. People were actually inspired to invent forms of democracy that would give again to the term its original meaning: "the rule of demos" (the people in Greek). And in all cases they chose to experiment with direct rather than representative democracy, which in many countries was connected to corrupt politicians and established oligarchies.

"Means should look like ends" seems to have been a guiding principle for the squares' organization, even if this formulation was not always explicitly stated. And this actually has heavily influenced both the squares movement legacy and the initiatives that were inspired by this legacy. Although ideological debates about the true meaning of democracy were in abundance during that period, collective experiences of democracy shaped both the key ideas and the practices which flourished in the occupied squares.

SOCIAL MOVEMENT STUDIES, Online Supplement, Fernández-Savater \& Flesher Fominaya (2016) 'Life After the Squares', available at: www.tandfonline.com/toc/csms20/16/1 
Far from being the result of spontaneous actions, these experiences of democracy actually produced as well as tested new forms of organization and collaboration. The Syntagma square occupation, for example, produced experiences of democracy-as-collaboration both at times of police violent attacks and during everyday discussions for the distribution of the square's maintenance tasks. Bodies experienced democracy as collaboration without a coordinating "outside" (a leading or decision - making group, a committee etc.). Experiences of collaboration of this kind produced forms of organization that were both efficient and exemplary. Feeling that you participated in a multifarious coordination of actions inspired by the same principles of respect for differences (oriented towards a shared longing for justice, democracy and equality) made you a responsible and inventive individual. It is remarkable how, for example, people managed to coordinate themselves to clean one day the square from poisonous teargas remains by forming chains that brought water from the central fountain to the square's surrounding streets (Stavrides 2016: 173). Democracy in action meant democracy of action. Embodied and "felt" democracy.

The squares movement experiences contributed to the invention (or re-invention) of forms of participative democracy that depart from the dominant models of social organization based on the idea that the state establishes and guarantees social cohesion in complex societies. Far from being an intrinsic limit to the movement's organizational capacities, direct democracy became a strong weapon for struggles that were not based on negotiable demands but on the predominant collective effort to go beyond existing rules for "making politics".

Staying in the squares and organizing a temporary settlement based on solidarity and the sharing of available means and resources was an opportunity for the squares' movement to explore and redefine the limits of the public domain. Public spaces in central metropolitan areas were converted to crucibles of new practices of publicness. If public space is space controlled by a certain authority which authorizes the use of the area under rules, defined 
by this authority, common space is that kind of shared space which emerges in acts of collaboration that establish rules of good use (Stavrides 2016). In common space people are invited to co-produce both the means and the scopes of sharing space. But, at the same time, common space is a necessary means to develop and expand practices of commoning. The occupied squares re-invented common space by defying the limitations, control mechanisms and ceremonial symbolisms embedded in public space. This was not simply the result of a well-known practice in which protesters camp outside a government building in order to pursue effectively their collective demands. The squares movements' tent cities became the expression of a collective will to explore new forms of life-in-common. It is here that we must locate the most enduring impact of the squares' experience. By developing patterns of collaboration in order to be able to maintain a kind of shared space that admits newcomers and encourages the expression of different life values as long as they accept the scopes of sharing, the occupied squares showed that solidarity may produce new habits and rules of living together.

Common space has been rediscovered after Syntagma square occupation in lots of initiatives connected to efforts to resist the devastating effects of a socio-economic crisis. Self managed health clinics, collective kitchens cooking for the poor, self-managed social centers and neighborhood cultural and educational initiatives have spread all over Athens, all over Greece. All those initiatives develop their own way of sharing space, recourses and services produced by active participants. Open to newcomers, self-managed and always expanding, the Syntagma common space re-emerged in a myriad of commoning practices in and against crisis. Collective and individual needs are being re-defined through those initiatives. But, more than that, subjects of action are being redefined too. A volunteer doctor in a self managed "social clinic" is a citizen-doctor, an active participant in the formation of new relations of collaboration and solidarity. So is a volunteer teacher of 
Greek language in a social center school for refugees and immigrants. So is someone who cooks in a collective neighborhood kitchen.

Syntagma square occupation indeed "generated an explosion of creativity and cultural production". Ad hoc feasts, the sharing of music and singing as well as improvised theatrical acts and happenings were part of the occupied square's everydayness. One interesting detail (that may have characterized other occupied squares too) is the way those cultural events contributed not only to the dissemination of the movement's demands and aspirations but also to the movement's own protection from police violence.

Police riot squads attacked the square in various occasions and with different "official excuses" ("obstructing circulation", "damages to public property", "imminent criminal behavior" etc.). In many cases cultural creations and artistic performances became the means to organize resistance to such attacks, to keep the spirit high and more than once, to even intercept police aggressiveness by ridiculing the invaders who had to face drums and songs instead of stones and molotovs.

Beyond the often paralyzing dilemmas of counter-violence (against police brutality) $v s$ "pacifism" lies another option: to immobilize mechanisms of state violence through mockery and festive collective acts which destroy the official rhetoric that presents state aggressiveness as necessary law-enforcement tactics in defense of "public security". Such inventive acts may be connected to the long tradition of charivari-like performances (Thompson 1993) which have often expressed the resistance spirit of "those below" by avoiding, at the same time, disastrous confrontation with stronger opponents.

Many of the tactics of struggle of the square's movement were based on the participation of people, on the enthusiasm generated from collective coordination and on the creativity unleashed by acts of disobedience. Tactics were discussed in the Syntagma square assembly as in many other square occupations. But there was always space for 
improvisation and, often, innovative acts of dissemination and resistance became catalysts for new collective initiatives. It is this spirit of emerging popular creativity, combined with a growing distrust for the "authorities", that has been circulating in the society's body as a peculiar "regenerating virus" ever since. Militant activists usually observe societies in search for acts of insubordination, in search for major events that are appear to inflict major changes. Maybe, however, ruptures in history only express changes that were being developing tacitly, often below the radar of dominant media in everyday acts that, seemingly, only breed consent and obedience. If Syntagma square occupation was indeed a surprise this is not because it came from nowhere completely bypassing established politics (dissident politics included), but because those who consider themselves as engaged in the struggle for human emancipation don't pay attention to minor events of discontent, to molecular acts of resistance and to aspirations for a more just society that often punctuate people's everydayness. Thus, if we want to trace the potentialities released by the squares movement we need to abandon the erroneous clear-cut dichotomy between dissent and normality. Those movements have indeed subverted the normalization process necessarily connected to the mechanisms of power (Foucault 2009). But they have done something more than that. Something which is less easily traceable. They have shown that our lives can be otherwise, that collaboration may produce humane relations and joy, that "we are many" and those who destroy our lives are very few. Delegitimization of power, demythologizing of state violence and the revelation of injustices did not result in the paralyzing view that nothing can be done, that politics stinks, that the powerful are invincible. Squares produced real tangible alternatives both to politics, to the everyday survival tactics and to the existing forms of social organization. And those alternatives are bound to breed new eruptions of collective inventive resistance.

Some argue that the squares movements have in a way catalyzed changes in the political system of the corresponding countries. Obviously this is not the place to trace such changes 
in the Arab world. But we should not forget that those movements have overthrown governments in Tunisia and Egypt and have contributed to the formation of left-wing and "political Islam" initiatives.

The most commented upon changes in Europe have been, of course, the cases of Podemos in Spain and Syriza in Greece (some also see relevant dynamics in Jeremy Corbyn's election as head of British Labour Party). First of all, there is a big difference between Podemos and Syriza. Whereas the first one was indeed created after the Indignados square occupations by people directly involved in them, the second one pre-existed the Syntagma square movement. Syriza did not officially participate in this movement. No party was allowed to do this, anyhow. Strong skepticism was the initial response to the occupation by many of the Syriza members and officials. One of the most often expressed objections had to do with the prevailing anti-parliament slogans of the square, which, especially in the first days, seemed to lean towards anarchist (or, for some, even fascist) counter democratic views. The days and events that followed have convinced many party members to join the occupation as individuals and actively contribute to its organized initiatives. Certain Syriza intellectuals also took part in open discussions organized in the square on the topics of democracy, public debt, education etc.

What connected Syriza to the square movement was, probably, the growing feeling that after the decline and the evacuation of the square and the continuing violent suppression of strikes, only a government change could at least protect people from devastating austerity policies. One can even argue that Syriza rose unexpectedly to a government party not simply after the movement was defeated but because this movement was defeated. Maybe however, as in the case of the obscuring dichotomy of normality $v s$ dissent, things are not so simple. Clearly Syntagma produced a momentum of dissidence that propelled to power a party that was not connected to dominant politics although it was, equally clearly, part of the existing political system in every aspect. Thus, the rise of Syriza expressed a true 
collective will for change. But Syriza, as we know, is very far away from its promises. Nowadays, the Syriza based government is absolutely following the policies that the party used to condemn before it came to power. And more often than not this is presented by government officials as a necessary reconciliation with powerful enemies or as a series of small victories in an asymmetrical war. In both cases, the official rhetoric is following the good old tactics of giving new names to old policies and of disguising brutal neoliberalism as opportunities for development and economic growth.

Syriza's rise to power expressed the potentiality of giving to society the means to defend itself. And Syntagma spirit was there in the enthusiasm of the first days. But this momentum was lost not only because the Troika vultures were simply paradigmatically trying to crush whatever political change might create conditions that challenge its predominance. Syriza officials and especially those around the Prime Minister Tsipras clearly chose to consent to neo-colonialist agreements and to abandon any measure that might relieve the most vulnerable.

A recent important come-back of the Syntagma insubordination spirit should be mentioned: Tsipras had decided to organize a referendum in response to a Troika proposed new memorandum of agreement, even harsher the previous one. It seems that he wasn't at all prepared to see this referendum end up in a massive $62 \%$ "No", in spite of right wing propaganda, in spite of outright blackmail declarations from EU and IMF officials, in spite of the closing of banks which sent a message of imminent state bankruptcy. The collective effervescence of those days was similar to the joy unleashed during square occupation days. People collectively overcame fear.

Distrust for the state considered as the protector of the society's well-being. Distrust for official democratic rules and the system of "representative democracy". Distrust for established political parties. The squares have not simply expressed such shared feelings of distrust. They have mobilized people in search of ways to take their lives in their hands. 
In Greece, initiatives meant to defend the most vulnerable and underprivileged (including immigrants and refugees) evolved to a loose but expanding solidarity network. Often starting with a will to satisfy an urgent collective need, those initiatives contained from the beginning the seeds of new relations between the people involved. In today's self-managed centers for refugees who were harshly denied their rights both by the EU and the Greek government, (which admittedly differs in some aspects from certain outright racist ones in Europe), very important acts of organized cohabitation and collective everydayness take place. Refugees are encouraged to participate in assemblies which take decisions about the way those centers will function (mostly abandoned re-occupied buildings). In this process, new subjectivities are being shaped through participation and the mutual recognition of differences, new forms of understanding what it means to have rights and obligations develop.

A lot has been said about the prefigurative character of the squares movements' politics. Did those events provide the breeding ground for forms of life that prefigure a more just and egalitarian society? Perhaps yes, if we always keep in mind that people were discovering (or re-discovering) the power and beauty of solidarity not necessarily because they were ideologically convinced for the need for socialism (or whatever name one may give to human emancipation). Prefigurative politics were in many cases the result of many dispersed acts of collaboration as well as of many explicit collective decisions aimed at the coordination of struggles. This is perhaps why we should learn to be more cautious when we distinguish prefigurative action from mere demand-centered organized struggles. Squares movements seem to have lifted the barrier that separated those two areas of collective action. Initiatives were and are explicitly oriented towards transforming crucial aspects of society today, in the present time. And those initiatives (either directly connected to the occupied squares or not) directly affect the lives of those involved in them. At the same time, such expressions hint towards a rethinking of politics, towards a retesting of the 
rules of equality and justice in and through commoning practices. A re-invention of politics? A re-invention of democracy? Or, perhaps, a re-invention of the future at times when neoliberal orthodoxy tries to establish itself as the only possible way to organize societies. The dissident spirit of the squares is bound to re-emerge in different ways during a period of prolonged social-economic and cultural crisis. As in the important political experiments of self-management in Rojava region (Northern Kurdistan, Syria) and the Zapatista region (in Mexico), efforts to construct a different society may even flourish during the harsh conditions of war (latent or explicit war). It is in and through crisis, perhaps, that glimpses of such different social relations may emerge in, against and beyond capitalist horror.

\section{Egypt/Tahrir (Wiam El-Tamami)}

\section{Where we are now}

Dear Cristina, dear Amador,

I wanted, first of all, to thank you for your questions. We were impressed by their thoughtfulness, their thoroughness, and the way they seemed, implicitly, to trace out a trajectory that we could relate intimately to the events here in Egypt, and which we hadn't realised was possibly shared — by other 'movements of the squares'.

The questions themselves - even before we began to attempt a response - gave us a sense of overarching perspective, and made us feel less alone.

I read the questions with two of my most trusted friends in Cairo, with whom I have shared all the events of the past years since our lives were turned inside out in 2011.

Hani, 35, is a chemical engineer whom I met in Tahrir Square shortly after the fall of Mubarak. For a few years before the uprising, he had been interested in politics, and he 
began to get active in 2010, one year prior; but the uprising galvanized this into a passion and a calling and he joined two political parties. Hala, 55, is a botanist, conservationist, and former university professor, who quit her full-time job shortly after the uprising began and gave free reign to her many other talents: she is now, among other things, a Food Sovereignty/Food Rights activist and consultant, a vegetarian cook and caterer, a designer with her own line of clothing made from upcycled/unusual/local and found-through-travels materials, and a yoga teacher who recently opened her own studio in downtown Cairo.

I read the questions out to Hani as we took a walk through downtown Cairo. We briefly, jokingly considered sitting at an ahwa (street cafe), but knew it wouldn't be the best place to discuss questions like these. We walked past Bursa, a cobblestone street that used to be lined with ahwas, with shisha and glasses of tea and animated discussions about everything that was happening in the country; now the street has been completely cleared of these cafes. Hani said it was depressing, and hurried on. Many people have been arrested just sitting at cafes or even walking in the streets of downtown.

We finally sat at Felfela: a couple of streets away from Tahrir Square, this stuffy old restaurant, a downtown institution that used to be frequented by locals and tourists, had been our go-to place in those early months of protests, heaving with people taking a break from the square to have a bite to eat or a drink after an hours-long march.

Felfela was dim, only a few tables occupied, the entire inside hall now closed because tourists were no longer coming to Egypt. Hani indicated a waiter standing in the corner, asking if I still remembered that man. Yes - I had mentioned him in a piece I had written during the second, violent wave of the uprising, a week-long battle between protestors and police on Mohammad Mahmoud street in November 2011. We came to Felfela one day that week and were surprised to see that waiter, younger than the others, with a telltale sign

SOCIAL MOVEMENT STUDIES, Online Supplement, Fernández-Savater \& Flesher Fominaya (2016) 'Life After the Squares', available at: www.tandfonline.com/toc/csms20/16/1 
on his face that he, too, had been involved in that violent confrontation with the police, in which hundreds of young demonstrators were killed: "A waiter we knew, with a straight solemn back and a skinny wolfishness, had small dark holes in his face. Pellets; we'd learned to recognize them by now. I couldn't imagine him out of his straightlaced blackand-white uniform. I tried to imagine him throwing rocks." And there he was, still here, after everything that had come and gone.

\section{Repression}

There has, indeed, been a counter-revolution. Repression is back full force, worse than anything witnessed before the uprising, during the Mubarak era - worse than anything seen before by our generation.

We were intrigued by your question about whether there have been 'new forms of repression'. Hani's response was: "Well, repression is always the same, isn't it? You jail people, you torture people, you kill people."

And indeed the regime that took over in the military coup of 2013 has been doing all of the above with impunity. According to Human Rights Watch, ${ }^{12}$ "Authorities have effectively banned protests, imprisoned tens of thousands — often after unfair trials — and outlawed the country's largest opposition group, the Muslim Brotherhood. A sweeping counterterrorism law has expanded the authorities' powers. National Security officers commit torture and enforced disappearances, and many detainees have died in custody from mistreatment. The government continues to investigate independent NGOs and put journalists on trial."

And they are lashing out in wilder and wilder ways. Giulio Regeni, a Cambridge $\mathrm{PhD}$ student from Italy who was doing research on Egyptian labour unions, disappeared in Cairo on 25 January of this year, the fifth anniversary of the uprising. His body was found 9 days later in a roadside ditch. He had been burned, brutally tortured, and mutilated — "a murder that bears all the hallmarks of Egypt's security forces." After many strange and inconsistent

SOCIAL MOVEMENT STUDIES, Online Supplement, Fernández-Savater \& Flesher Fominaya (2016) 'Life After the Squares', available at: www.tandfonline.com/toc/csms20/16/1 
stories, the authorities made what seemed to be another botched attempt at a cover-up: killing 5 Egyptian men in a shootout and claiming they were a 'gang' who had murdered Regeni. And when members of the murdered men's families spoke out to the press, pointing fingers at the national security forces, the family members themselves were detained (as was the legal advisor to Regeni's family).

In April, Abdel Fatah al-Sisi signed a deal to transfer two Red Sea islands to Saudi Arabia, which sparked a wave of protests. A crackdown ensued in which 1300 people were arrested in the space of two weeks, in random sweeps of streets and cafes as well as house visits and targeted pick-ups, including prominent human rights defender Malek Adly. In May, police stormed the Press Syndicate for the first time since its establishment in 1941, beating security guards and detaining two journalists. Journalists responded by staging a gathering of thousands at the syndicate, calling for the release of all imprisoned journalists and the dismissal of the Minister of Interior. It was a strong statement, but by the end of the same month the head of the Press Syndicate himself was arrested, along with two colleagues, in what Amnesty International called "the most brazen attack on the media the country witnessed in decades ... [which] signals a dangerous escalation of the Egyptian authorities' draconian clampdown on freedom of expression and demonstrates the extreme measures the authorities are prepared to take in order to tighten their iron grip on power."

I was part of a conversation the other day where someone was saying, quite matter-offactly, that "anyone interested in public affairs should prepare themselves for the prospect of prison - it's that much of a possibility now." He was talking about his own sister's arrest and the 'logistics' of which prisons are better than others, how to bribe officers, have supplies sent in, get a phone call through, etc. — like that is all part of the vocabulary of our experience now.

SOCIAL MOVEMENT STUDIES, Online Supplement, Fernández-Savater \& Flesher Fominaya (2016) 'Life After the Squares', available at: www.tandfonline.com/toc/csms20/16/1 56 
I am thinking now, as I write this, about how nationalism has become a tool for repression. Since the military coup, the discourse has consisted almost entirely of "You are either with us, or you are against Egypt. If you are not with us, you are a terrorist intent on destroying this country." How the media was deployed to crack apart the movement, to tease open the cracks after the unified front of Tahrir into rifts and then extreme polarization.

Towards the end of 2011, walls composed of clumsy stone blocks began to be erected by the army around downtown Cairo, to block off major streets and thus, supposedly, stem the flow of protests; people reacted by painting magnificent street art on the walls in an act of creative defiance. And then, a huge barrier with an iron gate was built to close off Qasr el-Ainy Street, one of the main arteries. The authorities, quite cleverly, decided to paint that barrier with the colors of the Egyptian flag - some speculated that this was done in order to deter the street artists, as the penalty for desecrating the flag would be far more weighty than that for painting a wall.

And so it is with the discourse of this military regime, the central message being that Masr $f^{\prime}$ el gamee' - "Egypt is above everybody." During his many and increasingly megalomaniac speeches, Sisi often expounds, in that soft and chilling voice of his, on how he is doing all this for the good of Egypt, and we should all put aside our petty needs and desires for the sake of Egypt, and that there are those among us who have been planted to destroy Egypt, so we should not listen to them and we should be sure to hand them in to the authorities, etc, ad nauseum.

New forms of repression? Perhaps new tools of monitoring. There is now the risk of being arrested because of one's posts on social media. Perhaps the most notorious case of this has been that of a 22-year-old student, Amr Nohan, who was arrested and sentenced to 3 years in jail for photoshopping Mickey Mouse ears onto a picture of Sisi. The image, of course, went viral.

SOCIAL MOVEMENT STUDIES, Online Supplement, Fernández-Savater \& Flesher Fominaya (2016) 'Life After the Squares', available at: www.tandfonline.com/toc/csms20/16/1 
But Hani also had a more positive perspective on this: that this huge, unprecedented wave of repression is a wild, brutal, seemingly panicked reaction to a huge, unprecedented wave of energy and dissent that they are doing their utmost to stifle. They are trying to bring everything back to ground zero, to the swampland of stagnation and lethargy that was the general state in Egypt before 2005. And, in spite of their best efforts, we believe that they cannot but fail.

\section{Fear}

The question of fear is an interesting one. Yes, in many ways, fear has been re-instilled, inculcated back into society.

There are several layers or aspects of fear. For those, especially, who were involved in the uprising, their lives and their freedoms seem to be at risk, more than ever before. The psychological burden that many are bearing is immense; many seem to be buckling under its weight. The collective feeling of massive failure, loss, and decimation of our - what seem now to be - youthful dreams, our daring to believe that things could be different, is crippling.

Aside from this sense of personal insecurity and fear, there is also a general state of insecurity and fear that the whole society seems to be steeped in at the moment. Amid a crumbling economy, the threat of terrorism, a region where many states seem to be imploding, there is a simmering, underlying panic that Egypt will also go over the brink, descend into a chaos from which there will be no return - and, of course, the regime is benefiting from this. It is continuing to play upon this sense of panic to maintain its grip on the country. This makes for something a political deadlock, for which there seems to be no current solution, as I believe people in general don't want to do anything that might further destabilize the country, and there seems to be no alternative at the moment other than our beloved, 'rock-solid' armed forces. 
On personal fear: I would not go down to a protest now. The risk is too high. I try to tell myself that my battle is elsewhere, and indeed it is - and yet I cannot say that I don't believe that it is still important for some of the battle to be expressed on the streets - and others, the ones who still dare, are paying a heavy price for keeping it there.

Of the people who were arrested at the 'islands' protests last month, 33 were sentenced to 2 years in jail, and 47 to 5 years in jail. For taking part in one protest.

And yet, at some point in 2011 and in the subsequent months and years, a dam was smashed. You cannot erect another barrier in its place and pretend that nothing has ever happened. You cannot make people un-see what they have seen.

Along with the aforementioned fear, there is a sense of awareness - even entitlement which cannot just be snuffed out.

Our horizons have been broadened beyond any possibility of 'repair'. Through the uprising, there has emerged a collective 'we' that we didn't know was there, and these expanded social spheres are being sustained through social media. We are able to access and follow and interact with and campaign for and find out about and feel responsible for so many whom we consider 'our own' - our comrades, our detainees . . . the kidnapped and the killed, the disappeared and the released .... (as Hani pointed out, this can also be enormously exhausting and depleting — he doesn't know if we are 'humanly capable' of caring for and carrying the burdens of so many, especially in such a time of crisis.)

Aside from this - and not just for those who were involved directly in the uprising there has been an exposure to a whole Pandora's box of possibilities and alternatives, so many voices and critiques of whatever hegemonic discourse the state would like to see

SOCIAL MOVEMENT STUDIES, Online Supplement, Fernández-Savater \& Flesher Fominaya (2016) 'Life After the Squares', available at: www.tandfonline.com/toc/csms20/16/1 
imposed, so many ideas and projects and resources, endless glimpses into places beyond one's own life and known circles and country — so many worlds.

You cannot fill this awareness with empty promises. Prices rising, inflation, the economy disintegrating, tourism dissipating - every day there is a new crisis, a new catastrophe in the local news. Despite the aforementioned political deadlock, it is generally becoming far more acceptable now, socially, to criticize Sisi, who was once fervently above reproach the rumblings are rising.

'We know our way back to the streets ...' I feel that the idea of protest, of strikes, of collective action, of expressing objection and entitlement, even if not as active as it was a few years ago, is embedded in this society now and being used by different communities in different contexts. Brainstorming with Hani on recent examples of this, he spoke of three incidents of police violence - one in Luxor, two in different working-class neighborhoods in Cairo - against a local citizen, in response to which the residents of the area rose up en masse against the police. One example is in Darb al-Ahmar, where a policeman shot a young tuk-tuk driver dead, allegedly because of a conflict over the fare. This set the whole neighborhood aflame, people demonstrating in fury in front of the Security Directorate, and even using the slogans of the uprising (such as "el-dakhliya baltagiya/the security forces are thugs') - particularly interesting, Hani noted, because these are not necessarily areas that were known to be pro-change during the uprising.

Collective action seems to have become a more ready tool in the public vocabulary. From continuing labor strikes at factories, to the campaign to boycott the payment of electricity bills during the mass power outages of 2013-2014, to a strike by taxi drivers this year to protest ride-sharing apps Uber and Careem flooding the market. Another rather unusual recent example is that of Khaled Ali - a prominent dissident lawyer and activist who ran in the 2012 presidential race - filing a lawsuit to contest the transfer of the two islands, Tiran and Sanafir, to Saudi Arabia. Everyone thought it was an impossible case, especially

SOCIAL MOVEMENT STUDIES, Online Supplement, Fernández-Savater \& Flesher Fominaya (2016) 'Life After the Squares', available at: www.tandfonline.com/toc/csms20/16/1 
with the difficulty of finding documents to prove Egypt's sovereignty over the islands until he asked the public for help and it began pouring in from all directions, hundreds of citizens sending in documents that helped to bolster the case. The State Council then refused to endorse the transfer of the islands, and the case is under review: 'it's still a big challenge and all possibilities are open,' Ali says.

Along with fear, there is enormous defiance.

Humor has been one of the most essential elements of our uprising from the start - no surprise, as it is an integral part of this culture: Egyptians are known as the comedians of the Middle East. But I still find myself continuously astonished by the nonstop torrent of whipsmart jokes and punchlines that are unleashed on social media, even on such dark days as these, even — and especially — after every disaster. I remember once describing it this way: "After every absurd twist, the jokes would begin to surface like a collective exhale lifting the sky back into place."

With the current clampdown on all forms of dissent, there are fewer expressions of this in a sphere more public than social media, but some, remarkably, remain. 'Atfal Shaware' (Street Kids) is a group of 6 young friends who shot silly, satirical videos on a phone camera, selfie-style, mocking societal norms, the government, nationalist fervor, and even, most daringly, Sisi himself, and uploaded them on YouTube. They were arrested last month. A large campaign followed on social media, of people taking selfies of themselves with their phone cameras in front of their faces, directing a defiant challenge at the general himself: 'Does a Phone Camera Scare You?'

A spate of arrests and 'house visits' preceded 25 January 2016, this year's anniversary of the uprising, in an attempt to deter anyone from even thinking of taking to the streets. Frustrated by the impossibility of going out or taking action in any way, a young comedian 
inflated condoms to look like balloons and presented them to the police lining Tahrir Square - who were surrounded only by a few pro-regime 'noble citizens' waving flags and singing nationalist songs. He claimed they were "a gift from the people" to "celebrate Police Day." [The January 25 uprising was deliberately planned on that day because its initial seed was a protest against police brutality.] After he uploaded the video on YouTube, the backlash against this once-popular comedian was enormous, including being fired from the primetime television show where he was appearing, and threats to his personal safety. But he went on to publish a powerful status on Facebook, which was shared and commented on by tens of thousands of people. It starts off as a challenge: "What happened? Why did you all get so upset? I'm joking ... I didn't even shoot a protestor's eye out or drag a girl through the street and strip her of her clothes ..." He goes on to talk about his involvement in the uprising, all the violence he witnessed from security forces, and his subsequent feeling of depression and powerlessness; how most of his friends have sunk into a deep silence, trying to forget. He asserts that we will not and cannot forget, and that, despite being utterly terrified and feeling that his days outside prison are numbered, he will continue doing what he thinks is right. He ends the status by saying, "See you all in another world where we can be free, where we can laugh without being thrown in jail." In the end, he was not arrested.

On acts of defiance: Sanaa Seif, a 22-year-old activist, had just come out of jail in September 2015 after serving 15 months for participating in a protest, but that didn't deter her from risking another arrest by embarking on a one-person protest though the deserted streets on Jan 25 2016: walking alone, boldly, on the fifth anniversary of the uprising, retracing the route the protestors had taken on that day and many others, from Mostafa Mahmoud Mosque to Tahrir Square, wearing a sweater which said on the back: 'It's Still the January Revolution.' A few months later, when "summoned for questioning on accusations of inciting protests, she refused to answer the investigating judge's questions. 
She told him she would not participate in the 'charade' and said the courts and prosecutors all follow the will of the government. Stunned and offended, the investigator didn't charge her with incitement; he charged her instead with insulting a government employee while performing his duties. Within days, Seif was tried, convicted and sentenced to six months in prison. She refused to attend the trial and then refused to appeal the verdict. On May 14, she gave herself up to authorities and is now serving her sentence in a prison outside Cairo. 'It's not an act of bravado. Being jailed is not easy and I know it,' Seif wrote on her Facebook page before turning herself in."

What kind of internal freedom does this take? A friend of mine posted a picture on Facebook of the sea at Alexandria, with a single bird flying high above the waves, illumined in a ray of the sun's light. The picture was beautiful enough to give me pause, until I noticed the caption he had given it: 'Sanaa'.

There has been another incredible development, a collective act of defiance, this past week. The verdict of 5 years' imprisonment for the 47 people arrested at the islands protests was appealed, and they were given a 100,000 EGP fine instead - each; a total sum of 4, 700,000 EGP. (Roughly 10,000 EUR each - 470,000 EUR in total.) This is an enormous amount of money in Egypt. And yet, activists were adamant that we could come together and collect this money to free the detainees. This was complicated by the fact that the money could not be collated into a central bank account, because of the authorities several political parties were approached for this purpose, but all declined. So began a hand-to-hand campaign, collecting small amounts of money from thousands of people, through word-of-mouth and social media posts - and within one week the entire sum had been gathered, and the entire group of detainees could be released.

Within a day of the campaign's success, the other group -33 people who had been sentenced to 2 years' imprisonment for the islands protest - were acquitted on appeals. My mother's euphoric interpretation of this (which may well be true, but of course who 
knows) is that the authorities wanted to avoid giving people another reason to come together.

I am still astonished whenever I think of this - especially how it was gathered, in this underground action, just like that, physically, hand to hand, in small amounts, against the odds. As Hani said, there are still so many of us that desire change in this country, who know that things could be different. The success of this week's campaign — this coming together - seems to have invigorated many. Though we are not able to organize mass movement in the streets right now - there is energy and movement in so many other spheres.

\section{Absences}

The question of absences is a crucial one. "Were the great absences of these movements (i.e. absence of leaders, absence of structures, absence of programs) strengths or limitations?"

There are many ways to look at this, but one interesting perspective that Hani said was that the uprising was in its essence about the 'smashing of idols and legends' - I take this to mean the smashing, in a most basic sense, of the fear and reverence surrounding the leader figure. How many times did we look up during a march to see that the person now leading the chanting, as it shifted in waves through the crowd, was a 12-year-old girl, or a child, or anyone - anyone? Regardless of who they are, regardless of gender/age/class and all the other things that define hierarchical standing in this society. I believe that the fact that the uprising was leaderless meant that every one was a leader - and this meant an immeasurable sense of personal empowerment. What has now happened to this empowerment is an open question, but I do believe it is not something that goes away easily, and it is still expressing itself in many people's lives.

SOCIAL MOVEMENT STUDIES, Online Supplement, Fernández-Savater \& Flesher Fominaya (2016) 'Life After the Squares', available at: www.tandfonline.com/toc/csms20/16/1 
Hala, when we were talking in a different context, mentioned a poem that I had forgotten and which I am now thinking can also be related to this. It had come out of the uprising, written by a young man named Moustafa Ibrahim, and was later made into a song. It's called Fulan el-Fulany, which literally means 'So-and-so' (in the sense of someone nameless or unnamed). The poem begins:

So-and-so who was standing next to me that day,

the day the shooting began,

So-and-so whose name I don't know,

so I just called him 'my cousin'.

It goes on to talk about so-and-so who gave you the rest of his sandwich when you were hungry; so-and-so who gave you a blanket and asked if there's a space next to you on the pavement; so-and-so who soaked your scarf with vinegar and handed you bottles to fill with gasoline; so-and-so who never appeared on a television program, whose voice was only heard in the heart of the protests; so-and-so who carried you the day you were shot... It takes a couple of lines to understand that the poet — himself an unknown — is not talking about one person, but about so many, that this uprising was all nameless ones, standing side by side. The fact that there were no leaders meant just this: we were all one person, just one. We were many and one. And we did it ourselves.

\section{Initiatives}

On the plethora of initiatives that were born in the square, Hani's response was: yes, many of them have fizzled out, but the impetus to do something is still very much alive and expressing itself in a multitude of ways. He was referring to collective action, coming together to do something - even to what he called 'the idea of ideas', the act of generating ideas collectively which he says is still a very active impulse in their political party right

SOCIAL MOVEMENT STUDIES, Online Supplement, Fernández-Savater \& Flesher Fominaya (2016) 'Life After the Squares', available at: www.tandfonline.com/toc/csms20/16/1 
now. My tendency is to think of things from a more personal standpoint, on the level of the individual, and so I also feel that the impetus to do something in one's own life, to enact some personal change, has been a fundamental aspect of this movement.

It is interesting that we use this word - 'a movement' - which means also, simply, motion, the act of changing place or position, the opposite of stasis; it is the same in Arabic, haraka. (And a word based on the same root, hiraak, is used to describe political energy, this giveand-take of aliveness and discussion and thinking, struggle, motion.) Now that the movement has been thwarted in many ways, with so much physical and psychological violence, many people have been left in a state of deep trauma, even despair. But I do believe that when we say 'the revolution has failed' we've lost sight of something so fundamental, so right in front of our eyes that we can no longer see it. We have lost, in many ways. But if we were to think back to how Egypt was before 2005: that swampland of corruption and stagnation and passivity. The general feeling was of inertia, that things were at a suffocating standstill; it felt like nothing would ever change and that there was no will to do anything about it. That very little was possible.

Even if they have tried to crush our movement, and to crush us - and even if we are going through a phase of deep disillusionment and cynicism; even if we feel that we have aged beyond our years - there is still so much energy, so much movement, so much struggle and aliveness, on a personal, internal level as well as collective level — and it is expressing itself in other, less obvious ways.

\section{Forms of life}

The uprising blew society open. So much of what it contained became ripped out into the public sphere for all to see: all the diseases of society, hypocrisy, violence, prejudice, fragmentation. Especially in a society like this one, where good manners and social

SOCIAL MOVEMENT STUDIES, Online Supplement, Fernández-Savater \& Flesher Fominaya (2016) 'Life After the Squares', available at: www.tandfonline.com/toc/csms20/16/1 
'correctness' are prioritized in the common value system over truth, where so much was done 'under the table' - so much was blown open.

I think that for many of us who were involved in the uprising, in the midst of this mad din of confusion, there came a crucial phase of confrontation with the self: who am I? What do I believe, what do I believe in? Who are the people around me? What is my relationship with them, with society, with codes and hierarchies and belief systems? What is my role — and who do I choose to be - within this larger social matrix?

There has been a lot of painful and painstaking tearing down - recognizing and then beginning to strip away things that were once invisible or taken for granted, unquestioned. When upheaval comes, it shakes everything up. I and every one of my friends went through enormous personal transformation: in our lives, belief systems, friends and family, work, within. There was a lot of freeing oneself from the bounds of received ideas and limitations: family, religion, social codes governing behavior, sexuality, career paths, etc. So much was blitzed into shards and fragments that we had to put back together into some picture of how we want to continue from here.

And so much was revealed about people around us. When push came to shove, irreconcilable differences in values were revealed. When a group of people are killed and one person reacts by celebrating and the other by mourning (a husband and wife, or father and daughter, or two people who thought they had enough in common to be good friends), what happens next? There were divorces, estrangement, other big rifts within families. There was one divorce within my own extended family — the woman was a Muslim Brotherhood supporter and her husband pro-army.

There have also been endless other kinds of reconfiguration of family relationships. I see the way my little cousin stands up to her father and opposes him openly now in many daily decisions, especially — and particularly outspokenly and rudely — when he tries to say 
anything about the uprising. A new friend I was speaking with the other day said that he became very close with his siblings after the revolution, since they began to go to protests together. With me, as with others I know, the relationship with some members of my extended family is somewhat strained now; I remember a confrontation with my uncle, an army man, at the time of the Port Said football massacre, when he said 'those scumbag kids had it coming' (I wrote about that here).

Many people I know also had a big shift in their careers, quitting corporate/conventional jobs and moving towards doing things that speak more to who they are.

Interestingly, I see a lot of this in Istanbul too. Since moving there two years ago, I've met a remarkable number of people in the middle of a major life change. People who have quit 9-5 jobs and conventional pathways and started to find or build an alternative space for themselves, questioning their values, seeking out lives outside the city, trying to live a more natural life, one that more closely resembles who they feel they are. I'm convinced it has to do with the Gezi movement.

There was so much room to voice, voice, voice - sometimes until the voice becomes barren, breathless. The idea of expression - everything ex-pressed, out in the open, so much that in such a dualistic society was once unsaid . . . though I can't pretend that everything that was said was authentic or of value. There was a lot of shouting, which I don't think was conducive to thinking or understanding. We have to admit that the movement itself carried its own conformity - it was, in many waves, a wave that hurtled us all along. That protests at some moments became social gatherings. That we also in moments became polemical. Stood up against some things or people unthinkingly. Repeated the things we were supposed to say, reacted to situations the way everyone else was reacting, echoed the collective anger or panic or victory or fear or sorrow before stopping to think whether these feelings were really ours, or warranted in that moment.

SOCIAL MOVEMENT STUDIES, Online Supplement, Fernández-Savater \& Flesher Fominaya (2016) 'Life After the Squares', available at: www.tandfonline.com/toc/csms20/16/1 
That there was very little space or time, especially at the start, in the first year and maybe two, to take a step back and figure out how you really feel or where you really stand.

It feels like things have calmed down now, and people have taken a step back. Now it feels more like a choice - how involved do you want to be? How much risk are you willing to take? With things becoming more fragmented - less 'come along with us' or 'be left out', there is more room to figure out how and where you stand. How can I express what I want to express in my own life, or integrate what I've learned? (Or how can I save myself, in a place like this?)

Maybe now is an opportunity to let it all sink in. Many people have become crushed. Many have left the country. Many have withdrawn into their own lives. And many others are still struggling with the question of how and where to go on from here.

Speaking of ugliness coming to the surface: sexual harassment, which has reached epidemic levels in Egypt in the last two decades, seems to me to be one area in which we are beginning to see a shift in behavior/attitudes on a societal level. It went from being largely unacknowledged by the public - there was not even a term for it, people typically calling it 'mo'aksa' (something like 'flirting' or 'teasing') rather than harassment — to being brought into media attention and public debate, thanks to the efforts of many campaigners and civil society groups over the past few years. The summer of 2013 was a particularly dark hour for us all: this disease - and society's hypocrisy about it and blame of the victims - reached its ugly crux when, at the height of pro-military celebrations following the coup, a spate of mob sexual attacks against women began in Tahrir Square. (In the absence of any police or army response, task forces were set up by young volunteers to combat the crisis and extricate women and girls caught in the grip of these mobs, complete with control

SOCIAL MOVEMENT STUDIES, Online Supplement, Fernández-Savater \& Flesher Fominaya (2016) 'Life After the Squares', available at: www.tandfonline.com/toc/csms20/16/1 
rooms, hotlines, intervention teams, safe houses, and medical and legal attention for the victims — the only heartening thing during this sickening time.)

The following year, in 2014, a new law was passed criminalizing sexual harassment, and Cairo University adopted an anti-sexual harassment policy. There have been other gains on the issue since then. And visiting Egypt this year, I do feel that something has shifted on the streets. This is purely subjective and anecdotal, but from my observations and a quick survey among female friends, harassment seems to be less ubiquitous than it used to be. There's still a long way to go, but it feels like some tipping point has been reached.

\section{Cultural creation and expression}

There has been an explosion of creative expression since the uprising. It began in the square itself: I remember how amazed we all were by the signs people had hand-painted and were carrying around the square to express who they were and their frustration at the status quo, by this explosion of humor and creativity and color and eloquence. I remember a common feeling that we had no idea how much imagination there was in this country: imagination, like critical thinking, individualism, diversity, not being among the values nurtured in this previously rather conformist society.

And then how the walls around the city, especially the ones dotted around downtown Cairo and surrounding the square, began to explode into words and color, some into magnificent, powerful street murals depicting moments from the resistance, questioning and challenging, memorializing the lives lost — transforming the drab, grey walls of this city.

There's been a boom in all forms of art and creative expression since, and an increased interest in and production of alternative and independent art (though there are questions about quality). For me personally, it has been most visible in street art, in music, and in film.

SOCIAL MOVEMENT STUDIES, Online Supplement, Fernández-Savater \& Flesher Fominaya (2016) 'Life After the Squares', available at: www.tandfonline.com/toc/csms20/16/1 70 
The change in the independent music scene has been marked. I remember, coming to Egypt every summer as a child and teenager in the $80 \mathrm{~s}$ and $90 \mathrm{~s}$, how everyone awaited the release of a pop star's new tape and that was what everyone listened to; you could hear it blasting out of every car at a traffic light. Now, independent music has gained a lot of traction. There are labels for independent musicians; some are touring all over the Middle East and in Europe, and have developed a large local fan base. Two of my favorites are Youssra elHawary and Maryam Saleh, two women who also saw a huge transformation in their own lives since the uprising began (Youssra was not even a singer before the uprising - she was working as a graphic designer). Youssra's breakthrough moment was a subversive song, El-Soor (The Wall), in which she makes fun of the walls built around downtown Cairo by security forces in an attempt to stem the flow of protests. It garnered tens of thousands of views on YouTube shortly after being released. She continues to make songs that I feel are breaking new ground - with her accordion, her lyrics, her average-girl voice, and this subtle, charming, witty way of hers; songs which, among other things, mock the system, the establishment, stuffy social mores, hypocrisy and the status quo. Her song 'In the Street' details all the things that happen in the streets of this city - like people beating and killing each other - and ends with a twist: but 'what a scandal it would be if we absentmindedly kissed in the street!' In 'Masks', she makes fun of people in positions of power; in 'Hato Kteer' (Buy It All), she satirizes the Egyptian penchant for clutter and accumulating useless stuff. For some time she had her own popular radio show where she hosted independent musicians, chatting with them and presenting their music. Maryam Saleh is a very different musician - a powerhouse of different influences whom I believe truly began to tap into her inner power, even rage, and channel it into raw and powerful music since the uprising.

There seems to be a shift in the film industry, too. More alternative and independent films (including documentaries) are being made, and shown more widely — some very unusual 
films have even been shown in mainstream cinemas. An Egyptian film, 'Clash', which takes place entirely inside a police riot van, was very well received at this year's Cannes film festival. Even mainstream visual media - commercial films, television series (which were once composed entirely of melodramatic soap operas), and television commercials - are showing a great deal of innovation and technical progress, in response to shifting public tastes, audiences exposed to media from around the world and thirsty for impressive visuals and new ideas.

When I asked a filmmaker friend about these changes, he says that some of them have been slowly starting to happen since 2005 , so, to his mind, they have happened alongside the political struggle, rather than as a direct result of it — there was already a groundswell. But there can be no denying that the uprising galvanized all of these energies.

A friend whom I also met during the early days of the uprising, an established dancer and choreographer, went on to set up the first professional school of contemporary dance in Egypt. It even began under the auspices of the government, at the state-run Opera House, shortly after the uprising. But, after falling out with that institution, the school had to go its own way after the first year and managed to find an independent space and funding in order to continue.

Interestingly, both Hani and Hala (whom I spoke to at different times) brought up the issue of appropriation - Hala spoke at length about artists and other cultural makers who had appropriated the uprisings for their own benefits (she used the notorious example of 'A Gay Girl in Damascus', and how much that damaged the cause); Hani said - a bit more mildly but still quite a firm statement - that 'the art that came out of the uprising benefited from the uprising, but didn't benefit it', saying that, to his mind, the quality and content are still lacking.

SOCIAL MOVEMENT STUDIES, Online Supplement, Fernández-Savater \& Flesher Fominaya (2016) 'Life After the Squares', available at: www.tandfonline.com/toc/csms20/16/1 
I would beg to differ. Of course there is still a lot of soul-searching going on, artists emerging and searching for their voice, and the quality is inconsistent, but I feel that the creative arts are going through a rich and fascinating time of regeneration and exploration. The filmmaker friend I spoke to also mentioned another interesting point: since the uprising, independent artists across the Arab world have become more connected. I see this in music - there seem to be a lot of tours and criss-crossing of independent musicians through the Arab world, common networks, many Arab musicians from Amman, Beirut, Tunis performing in Cairo and having a local fanbase, and vice versa - as well as new collaborative projects such as the Alif Ensemble. He spoke about how it is also happening in independent film: that there is now a network of independent distributors across the Arab world, and how his experience with participating in collaborative workshops with other Arab filmmakers after the uprising made him feel that 'we have a lot in common, that our circumstances and experience is a collective one.'

So many cultural spaces have opened up! Zawya, Egypt's first arthouse cinema, opened in an old downtown theater, and screens a wonderfully curated selection of films. And endless other spaces, too many to count. Whenever I come back to Cairo I'm always amazed by how much is going on: there are always film screenings, concerts, gallery openings, talks, a multitude of workshops and classes - so many things to attend on a weekly basis often it is hard to choose what to do on any given night. And how fervently people imbibe it all!

This, above all, the fact of these audiences, is the major shift, I think. There are so many people who are hungry for something different, something that is non-conventional and not patronizing, something that expresses their emerging identity and aesthetic, their questions and struggles. Something unlike the stultifying homogeneity of what was available before. And I feel that people here in Cairo are imbibing this creative input that speaks to them with the urgency of those gasping for fresh air: works that are free-thinking, works of 
colour and originality in this toxic, polluted, oppressive air (interesting that car exhaust is called 'aadam in Arabic - the same word for absence, lack, nothingness). The more the spaces for dissent and expression narrow, the more vital and life-giving these things seem to be.

One fascinating element of the uprising - which I really hope some studies will be made about - is how the position of language has changed. Most of the young people in Egypt's privileged classes speak a foreign language fluently (English, French, or even German); in many cases, it is their first language, more fluent than Arabic, and Arabic is deemed inferior. The uprising changed this. Arabic gained a position of prominence and has become far more widely used by many young people in these classes, whether in spoken conversation or on social media (people writing in Arabic online used to be rare; now it is very common). National pride, the feeling of needing to speak and reach out across the social spectrum and develop a local language for the events - there must have been many factors, too many to go into here. (I've even heard of people using Yamli, a 'smart Arabic keyboard' for those who don't know how to type in Arabic or don't have an Arabic keyboard, where you can type in Arab words transliterated in Latin characters and it is transcribed into Arabic characters.)

There is also a current trend in places boasting 'local' things, especially food. This may well be a reflection of a worldwide trend for eating local, and although it is, so far, a bit of a pretentious/elite trend in Egypt, it is also interesting and seems to be an inward look at one's own culture rather than mass westernization. Some examples are Cairo Kitchen and Zooba, and many more are opening up.

A final note, and a completely personal observation: since arriving in Cairo this time, two months ago, I've noticed a change in people's appearance on the streets as well. I feel that 
women are wearing what they want to more than they did before, and I see a lot of men with long hair, dreadlocks, etc, which used to be a rare sight in this city where people's appearance used to be quite homogenous and conformist over the past couple of decades.

\section{How to carry on}

This video, called 'Life goes on in Damascus', expresses some of the things I have been preoccupied with lately.

A dance studio, a newly opened bar ... somehow it doesn't surprise me. Life always goes on and has always gone on: this is what we don't see on the news, everything that is happening beyond the close-up, the headline - all the ways in which people go on, even in the middle of upheaval and trauma and disaster. Even when violence is present, maybe especially when violence is present - life continues as a resistance to the eradication of life.

The video doesn't sugarcoat the situation or proffer a 'silver lining' approach. There is still the woman who lost her 6 children; there are still the deep dark circles beneath the eyes of the young dancer.

She says: 'Doing what we love saves us.'

Hala said this too:

'What can we do?

We have to live.

We have to celebrate life.

We have to do things.'

I was sitting around with some friends the other day when someone said: 'I guess we've come to a point where we either die, or we really fucking live.' 
I am thinking about Alia Mosallam and Lina Atallah's exchange of letters, how Alia spoke about going bird-watching on the anniversary of 25 January (Hala also reminded me of this). Coincidentally, I had also gone away into nature that day, and was listening to birds. I've been thinking so much about the idea of space. Space, space, space. When everything around is becoming so constricted - as 'the spaces narrow and narrow, like air squeezed out of a windpipe' - how is it possible to create space inside us?

More and more, I believe in doing what we love. I believe in creating microcosms, our own spaces that express who we are and how we believe things could be, enacting our ideas of the world, counter-systems, alternatives to institutions.

Like Naboo Cafe in Istanbul. Two of my Istanbullu friends, one a lawyer, the other a computer engineer, quit their jobs shortly after the Gezi movement and began to seek out a different way to be in the world. Among other things, they decided to open this cafe. It quickly became a free-wheeling space that attracted all sorts of people and where many different activities were going on and ideas were tested and played out - and felt, to all of us there, like our own home. An oasis, a world unto itself.

Like Fasahet Somaya in Cairo. Simply called "Somaya's space," a tiny one-room restaurant in downtown Cairo with a daily changing menu of Egyptian food, picked up from the market daily and made from scratch by one woman who rules the roost - a rather revolutionary concept in a city where the types of foods available to eat outside are usually very different from what is served at home. It is also a place that was always outspokenly pro-uprising and so became a little oasis-hangout in downtown Cairo for those circles. I was surprised to see, when I looked it up recently, that this tiny hole-in-the-wall place with 3 tables has 58,000 followers on Facebook.

Countless other creative hubs have popped up.

SOCIAL MOVEMENT STUDIES, Online Supplement, Fernández-Savater \& Flesher Fominaya (2016) 'Life After the Squares', available at: www.tandfonline.com/toc/csms20/16/1 76 
I also see, in Cairo right now, a wave of interest in training and tapping into the body. Many friends and acquaintances (most of them involved in the uprising, most of them not at all interested in sports before) are now doing everything from yoga to Crossfit to marathon running to swimming to Mixed Martial Arts to weight training to cycling (there is a growing subculture of cycling in Cairo), and I have recently even heard about a new kayaking group on the Nile.

I wonder about this trend. Does it stem from a desire to be physically strong and healthy to defy a regime that is seeking to annihilate our strength and will, even our lives? Or is it, less optimistically, a withdrawal into a preoccupation with the individual self after the collective has failed? Is it, after this season of bewildering confrontation with everything, a choice to focus on what one can change - oneself? Or, more cynically, an escape, an obsession with what one can control when insecurity encircles us, when everything around seems to be falling apart?

For me personally, I see the body, the mind, and the individual self as the first front of resistance - literal resistance to all of the pressures, oppressions, and distortions of nature that modern urban capitalist living demands - a polluted, overcrowded, heaving beast of a megalopolis like Cairo being an extreme example of this. That trying to protect one's body and mind from this barrage - trying to find alternative ways to live, think, breathe, and be is a fundamental act of resistance against the way things are, socially, economically, and politically.

Of course, having said all that, I can't help but wonder about class and means. In Cairo, thinking about one's desires when so many can't even meet their most basic needs often feels like a luxury, like navel-gazing. So many people have been crushed under the weight of this uprising and the instability that the whole country has been thrown into. As I write this, it feels like a luxury to be able to afford some time and headspace to even think about the idea of 'space' and contemplate how to 'do the things you love' . . but I am trying to 
resist thinking that way. (As Hala also pointed out, the internet has also enabled access to networks, ideas and resources that cross-cut the need for money.)

And aside from specific 'activities', we all have resources to tap into - we all have to find our ways of going on. Humor, family, friends, love. To keep finding small things that give some measure of happiness or pleasure. To find that freedom in our own lives, that independence in our minds. To live in a way that can somehow represent who we are and what we believe in, in spite of it all.

A friend posted this interview the other day with two American civil rights activists. I'm not sure I agree with everything that was said, but this rang true for me: "Self-care and healing and attention to the body and the spiritual dimension - all of this is now a part of radical social justice struggles. That wasn't the case before. And I think that now we're thinking deeply about the connection between interior life and what happens in the social world."

I would like to believe that, within this uprising, there is an element of resistance through introspection, through encounter with the self - that this is a primary element of these movements. This I would like to believe.

In the words of Junot Diaz in The Brief Wondrous Life of Oscar Wao: "But if these years have taught me anything it is this: you can never run away. Not ever. The only way out is in."

\section{The legacy of the squares}

Legacies.

The idea of facing up to society and to received, unqueried codes and values and ideas. Of confronting hierarchies and rules, taking on people and things that were in positions of unquestioned power.

SOCIAL MOVEMENT STUDIES, Online Supplement, Fernández-Savater \& Flesher Fominaya (2016) 'Life After the Squares', available at: www.tandfonline.com/toc/csms20/16/1 78 
The idea of personal power and collective power. Of heterogeneity and creativity. This infinite kaleidoscope of alternatives - alternative lives, ways of seeing and being - that has emerged and is continuing to emerge.

A legacy of deep exhaustion, too, of collective cynicism and disillusionment. (A joint artist exhibition last month in one of Cairo's downtown galleries was entitled 'Chronic: Exhaustion as a Collective State.') Many feel that they have grown old in the past couple of years, left their youth or some essence of it irrevocably behind, in this downward spiral whose end is still not in sight. Many have experienced violence, brutality, imprisonment up close, the power and reach of oppression, how its long claws can reach you, your own body, your life, or that of someone you love.

And yet, and yet. There is still so much movement, so much energy! Sometimes I feel that Cairo is such a tragedy: all these people who have to struggle to do or make something they believe in, having their lives drained out of them in the process; in this unrelenting megalopolis, in this atmosphere where there are attempts to thwart their efforts and passion and individualism at every turn by those who should celebrating their talents and supporting their ideas, who should help them to channel their contributions for the greater good. It feels to me that one's health and youth, one's will and drive is a higher price than anyone should have to pay.

And yet every time I come, I am so surprised by the vitality, in spite of everything, of this place. I remember, on a visit to Cairo last year, attending a wonderful live gig by Youssra el-Hawary, packed to the gills with young people laughing at her improvised jokes and singing along with her lyrics, followed by a lecture given by an old friend who started out as an architect and became a researcher and activist on built environment and social justice issues. I came out of these two events not knowing whether to be sad or to be defiantly glad. It struck me that unlike other places where there is less crisis, the work here feels so vital - in the sense of essential, necessary, urgent, and also in the sense of giving and 
being suffused with vitality, life-force. Despite this crushing city that crushes your body with its toxic air and crowds and traffic and unbearable noise, and a state that seeks to crush your will at every turn, there is so much going on, so much humor and ingenuity and artistry in spite of it all. People still thinking and discussing and creating and resisting and struggling with all of these questions. Is it a testament to the tenacity of life and human creativity and ability to adapt and persevere? Or is it too high a price to pay?

I don't know how to answer the question of whether this stage is a 'preparation' for another wave. The fact is that none of the problems that we rose up against have gone away; they have only gotten worse. None of the demands of the uprising, typified in its most salient chant: 'Bread, Freedom, Social Justice, Human Dignity' have been met. And, as I once wrote: "the generations younger than us are even more outspoken, switched-on, and nononsense than we were. As things deteriorate, I hold on to this thought." So there cannot but be other waves. But with the precarious situation the whole region is in, who knows how long it will take; who knows how much more things will unravel before another mass attempt to seek out different solutions is made.

But it is all still happening, still in motion. And this energy is far beyond any possibility of control - today's technology has enabled us to be in touch with each other, to get organized, in ways far more deft and fluid and creative than their stolidity, their old-school, blundering idiocy.

After that incredible gathering of 4,700,000 EGP in one week to free 47 detainees, one line from a famous song by Sheikh Imam - that old blind bard of resistance who was imprisoned under Nasser and Sadat and whose songs are still sung in revolutionary contexts — has been quoted often in the past week: "O Egypt, we are still many." 
I am reminded also of the Choir Project, a communal art project in which I was involved during its genesis in 2010-2011, where songs are produced by improvising the lyrics and music collectively at workshops open to everyone, and thus arise out of a spontaneous collective impulse - giving expression to whatever needs to be voiced at that moment. Less than two months before the uprising began, a song called 'The Pharaoh' emerged from the project (whose lyrics turned out to be eerily prescient: "The flood is coming . . . the flood is coming.") The song ends with the lines: "We'll throw mud on the wall — even if it doesn't stick, it will leave its mark." This feels to me an apt description of where we are now. It hasn't stuck, but it is leaving indelible marks.

So much is said about the 'failure' of the revolution - we now stumble on the word 'revolution' and say 'since 2011' instead, or ... what? I keep having to remind myself to delete the word 'revolution' while writing this piece and replace it with the word 'uprising'. But I think that the transformation, the sea-change, has been so fundamental that we cannot see it anymore because it is so big, everywhere and within.

And of course with every transformation (even within ourselves) there are moments of going backwards, there is a backlash, there is fear. We're in a difficult place right now, but I hope and believe that within the deep consciousness of this place, and of this world perhaps, things are shifting, and there is no going back.

From a text in verse I wrote in 2014:

we may be at a loss for words,

but we are not wordless

we are not bodyless

we are not songless

SOCIAL MOVEMENT STUDIES, Online Supplement, Fernández-Savater \& Flesher Fominaya (2016) 'Life After the Squares', available at: www.tandfonline.com/toc/csms20/16/1 


\section{ACKNOWLEDGEMENTS}

These reflections were written in May and June 2016. Cristina thanks Amador for his collaboration. We would like to thank all of our contributors for their generosity and reflexivity. Thanks to Sofía Eguiarte Flesher for her superb translation work. Thanks to Marianne Maeckelbergh, Mona Baker, Evgenia Michalopoulou, and Ana Bigotte Viera for helping us find some of our wonderful contributors.

To all those who filled the squares and who have continued to work for a better world, this is for you, and to the memory of those who never managed to leave the squares.

\section{NOTES ON CONTRIBUTORS}

Amador Fernández-Savater (Madrid, 1974) is an independent researcher and editor of Acuarela Books who has participated in various social movements (student, antiglobalozation, copyleft, "no to war", V de Vivienda, 15-M). Over the past years he has developed an understanding of his thought process as something fundamentally practical (useful without being utilitarian), situated, (that speaks from a concrete experience or place), collective (it is woven together with others around shared problems), defiant (that seeks not to leave the world the same as it was before) and implicated (that starts from questions one asks about ones own life).

He is the author of Filosofía y acción (Philosophy and Action) (Editorial Límite, 1999), co-autor de Red Ciudadana tras el 11-M; cuando el sufrimiento no impide pensar ni actuar (Citizen Network after 11-M: when suffering doesn't impede thinking or acting) (Acuarela Libros, 2008), Con y contra el cine; en torno a Mayo del 68 (With and against cinema: reflections on May 68) (UNIA, 2008) y Fuera de lugar. Conversaciones entre crisis y transformación (Out of Place: Conversations between Crisis and Transformation) 
(Acuarela Libros, 2013). Currently he is co-contributor and editor of the blog Interferencias in the newspaper eldiario.es. Email: amador@sindominio.net

Cristina Flesher Fominaya ( $\mathrm{PhD}$, Sociology, University of California, Berkeley) is Senior Lecturer (Associate Professor) at the University of Aberdeen. From September 2013-2015 she was Senior Marie Curie Fellow at the National University of Ireland, Maynooth conducting a two-year research project on anti-austerity mobilizations in Ireland and Spain. She is a founding editor of Interface Journal, and a co- editor of Social Movement Studies. She has participated in social movements since the 1990s, mostly in Madrid. She writes widely on social movements, politics, culture and digital media. Her latest book is Social Movements and Globalization: How protests, occupations and uprisings are changing the world, available from Palgrave MacMillan.

Hoda Elsadda is Professor of English and Comparative Literature at Cairo University; an activist for women's rights; co-founder and Chairperson of the Women and Memory Forum; author of Gender, Nation and the Arabic Novel: Egypt: 1892-2008 (2012); and member of the 50-committee that drafted the 2014 Egyptian constitution. When revolution broke out on 25th of January 2011 she resigned from her position as Chair in the Study of the Contemporary Arab World at the University of Manchester and returned to Cairo.

Luhuna Carvalho was born in 1980, and is an editor who lives in Lisbon.

Patricia Horrillo is a freelance journalist and recent feminist who, in the first days of 15$\mathrm{M}$, narrated via blogs and tweets what was happening on the streets and squares of Madrid. The experience was life changing and led her to participate in projects such as $15 \mathrm{~m} . \mathrm{cc}$ and 15Mpedia.org. Passionate about communication and social networks, she offers workshops on guerilla radio (Radio Guerrilla) and Wikiwomen (Wikimujeres).

Silvia Nanclares is a writer, and since 15M, also a cultural activist. She has developed collaborative research projects such as \#bookcamping or Hipster Sex (Sexo Hipster) and 
has published short stories and children's books. She contributes to numerous media outlets such as Diagonal, eldiario.es and Carne Cruda, and is a member of the communication and gender collective "Pandora Mirabilia".

Çiğdem, a journalist and activist, participated in the Taksim Gezi park occupations in 2013. Anonymous: In the USA, after an initial call for participation in the Free University, ten people involved in OWS got together to discuss the questions. These were later written up by two of them, both activists and academics involved in OWS from the very beginning.

Stavros Stavrides is an architect and professor at the National Polytechnic University of Athens and author of the book Towards the City of Thresholds (2010) contributes a reflective piece that responds in a more global way to the questionnaire but through the lens of the Greek Syntagma experience.

Wiam El-Tamami is a writer, editor and translator. She has lived in Egypt, Vietnam, England and Kuwait, travels far and wide, and is currently based in Istanbul.

\section{REFERENCES}

Deleuze, G., \& Guattari, F. (1988). A thousand plateaus: Capitalism and schizophrenia. London: Bloomsbury Publishing.

El Sadda, H. (2012). Gender, Nation, and the Arabic Novel: Egypt, 1892-2008. Edinburgh: Edinburgh University Press.

Flesher Fominaya, C. (2014) Social Movements and Globalization: How protests, occupations and uprisings are changing the world. London: Palgrave Macmillan.

Foucault, M. (2009) Security, Territory, Population: Lectures at the College de France, 1977-1978, Basingstoke: Palgrave Macmillan.

SOCIAL MOVEMENT STUDIES, Online Supplement, Fernández-Savater \& Flesher Fominaya (2016) 'Life After the Squares', available at: www.tandfonline.com/toc/csms20/16/1 
Hardt, M. (2014) Innovation and Obstacles I Istanbul One Year After Gezi, EuroNomade. Available at http://www.euronomade.info/?p=2557.

Stavrides, S. (2016) Common Space. The City as Commons, London: Zed Books.

Stavrides, S. (2010) Towards the City of Thresholds, Trento: Professional Dreamers.

Thompson, E.P. (1993) Customs in Common, New York: The New Press

\section{ENDNOTES}

${ }^{1}$ See also various wrtings by Amador Fernández-Savater in the blog "Interferencias" at http://www.eldiario.es/interferencias/.

${ }^{2}$ See Flesher Fominaya (2015). Redefining the Crisis/Redefining Democracy: Mobilizing for the Right to Housing in Spain's PAH Movement, South European Society and Politics, 20 (4) 465-485

${ }^{3}$ Hardt, M. (2014, June 4). 'Innovation and Obstacles in Istanbul One Year After Gezi.' Retrieved from http://www.euronomade.info/?p=2557

${ }^{4}$ UN. (2016, May 10). “Alarming' reports of major violations in south-east Turkey - UN rights chief.' $\quad$ Retrieved 19 September 2016, from http://www.un.org/apps/news/story.asp?NewsID=53895\#.V9_bKPArKM9

${ }^{5}$ BIA News Desk. (2016, February 19). 'Protest With Lights in Cerattepe.' Retrieved 19 September 2016, from http://www.bianet.org/english/people/172268-protest-with-lightsin-cerattepe

SOCIAL MOVEMENT STUDIES, Online Supplement, Fernández-Savater \& Flesher Fominaya (2016) 'Life After the Squares', available at: www.tandfonline.com/toc/csms20/16/1 
${ }^{6}$ See, e.g., Rahimi, S. (2014, May 20). 'Egyptian graffiti artists protest Sisi.' Retrieved 19 September 2016, from http://www.al-monitor.com/pulse/originals/2014/05/egyptganzeer-sampsa-street-art-sisi-graffiti-cairo.html

${ }^{7}$ Egypt Independent. (2011, February 23). 'Choir captures Tahrir revolution's Utopian vibe.' Retrieved 19 September 2016, from http://www.egyptindependent.com/news/choircaptures-tahrir-revolutions-utopian-vibe

${ }^{8}$ YouTube. (2013). Bassem Youssef's AlBernameg. Retrieved 19 September 2016, from https://www.youtube.com/watch?v=WYCF_rppZCY

${ }^{9}$ See http://www.madamasr.com/news/economy/1117-labor-protests-across-egypt-2015democracy-meter-report

${ }^{10}$ Freedom House. (2016). 'Country report: Turkey' in Freedom of the Pres, 2016. Retrieved 19 September 2016, from https://freedomhouse.org/report/freedompress/2016/turkey

${ }^{11}$ Yayo is the word for Grandparent and Yayoflautas (or Iaioflautas in Catalan) is a reference to a group of pensioner-age activists involved in 15-M and anti.austerity mobilization.

${ }^{12}$ Human Rights Watch: Egypt: https://www.hrw.org/middle-east/n-africa/egypt 